Türkiye Jeoloji Bülteni
Geological Bulletin of Turkey
$60(2017) 507-528$
doi:10.25288/tjb.363813

\title{
Geç Kuvaterner Buzul Buzullararası Döngülerinin Anadolu’nun Biyolojik Çeşitliliği Üzerine Etkileri
}

The Effects of the Late Quaternary Glacial-Interglacial Cycles on the Biodiversity of Anatolia

\section{Hakan Gür $\mathbb{D}$}

\author{
Anadolu Biyocoğrafyası Araştırma Grubu, Ahi Evran Üniversitesi, Kırşehir
}

Geliş/Received : 14.10.2017 • Düzeltilmiş Metin Geliş/Revised Manuscript Received : 09.11.2017 • Kabul/Accepted : 11.11.2017 • Bask1/Printed : 29.12 .2017 Derleme Makalesi/Review Article Türkive Jeol. Bül. / Geol. Bull. Turkey

Öz: Büyük kıtasal buz tabakaları, Kuzey Yarımküre'de Kuveterner boyunca birçok kez ilerlemiş ve geri çekilmiştir. Büyük kıtasal buz tabakalarının olduğu dönemler buzul dönemler, diğer dönemler ise buzullararası dönemler olarak bilinmektedir. Buzul buzullararası döngülere eşlik eden iklim değişiklikleri, ya türlerin yer değiştirmesine, değişen çevresel koşullara uyum sağlamasına ya da yok olmasına neden olur. Coğrafi dağılım değişiklikleri, türlerin bu iklim değişikliklerine verdiği en çarpıcı ve en iyi belgelenmiş cevaplardır. Türlerin Geç Kuvaterner buzul buzullararası döngülerine eşlik eden küresel iklim değişikliklerine nasıl cevap verdiğini anlamak için, ekolojik niş modellemesi, son zamanlarda biyocoğrafi çalışmalarda moleküler filocoğrafya ile birlikte yaygın olarak kullanılmaktadır. Ekolojik niş modellemesi, moleküler filocoğrafya ile birlikte, Anadolu'da yaşayan türlerin Kuvaterner dinamiklerini/evrimsel tarihini ve böylece Anadolu'nun biyocoğrafyasını anlamamıza katkı sağlayacaktır. Bu yazıda, yukarıdaki içerik açısından kuş ve memeli türleri ile ilgili birkaç örnek verilmiş ve gelecek perspektifleri tartışılmıştır.

Anahtar Kelimeler: Biyocoğrafya, coğrafi dağılım değişiklikleri, ekolojik niş modellemesi, iklim değişikliği, kuşlar, memeliler

\begin{abstract}
Large continental ice-sheets in the Northern Hemisphere have grown and retreated many times throughout the Quaternary. Times with and without large continental ice-sheets are known as glacial and interglacial periods, respectively. Strong climatic fluctuations accompanying glacial-interglacial cycles forced species to either move to locations that remain suitable, adapt to changing environmental conditions, or go extinct. Range shifts are the most conspicuous and best documented responses of species to these climatic fluctuations. To understand how species have responded to global climate changes through the Late Quaternary glacial-interglacial cycles, ecological niche modelling, together with molecular phylogeography, has been widely used in recent biogeographic studies. Ecological niche modelling, together with molecular phylogeography, will extend the Quaternary dynamics and evolutionary history of species living in Anatolia and therefore the understanding of the biogeography of Anatolia. In this article, a few examples regarding bird and mammal species were given to illustrate the above-mentioned contents, and the future perspectives were discussed.
\end{abstract}

Keywords: Biogeography, birds, climate change, ecological niche modelling, mammals, range shifts 


\section{GíRIŞ}

Bu yazıda, ilk olarak Son Buzul Maksimum örneği üzerinden Geç Kuvaterner iklim değişiklikleri, bu iklim değişikliklerinin (özellikle coğrafi dağılımlardaki değişiklikler üzerinden) biyolojik çeşitliliği nasıl etkilediği ve coğrafi dağılımlardaki değişiklikleri çalışırken yaygın olarak kullanılan ekolojik niş modellemesi yaklaşımı üzerinde durulmuştur. Daha sonra, Geç Kuvaterner iklim değişiklikleri ile Anadolu'nun biyolojik çeşitliliği arasındaki ilişki, kendi çalışmalarımızdan birkaç örnek ile tartışılmaya çalışı1mıştır.

\section{GEÇ KUVATERNER İKLIM DEĞIŞiKLIIKLERİ}

Dünya, Senozoyik (66 milyon y1l öncesinden günümüze kadar geçen zaman; bkz. jeolojik zaman çizelgesi için, www.stratigraphy.org/index.php/ ics-chart-timescale, Cohen vd. 2013) boyunca, daha doğrusu yaklaşık 50 milyon yıl öncesinden (Erken Eosen İklimsel Optimumundan) günümüze kadar yavaş yavaş soğumuştur. Bu soğuma sırasında, yaklaşık 40 milyon yıl önce Antarktika kıtasında buz tabakaları oluşmuştur. Kuzey yarımkürede buzullaşmanın ilk işaretleri, çok daha yakın bir zamanda (yaklaşık 10 milyon y1l önce) ortaya çıkmıştır (Past Interglacials Working Group of PAGES 2016). Kuzey yarımkürede büyük kıtasal buz tabakalarının ilerlediği ve gerilediği zaman dilimleri, sırasıyla buzul ve buzullararası dönemler olarak bilinir. Buzullararası dönemlerin buzul dönemleri birbirinden ayırdığı (veya tersi) buzul buzullararası döngüler ise, ilk kez Kuvaterner (yaklaşı 2,6 milyon y1l öncesinden günümüze kadar geçen devir) ve Pleistosen (yaklaşık 2,6 milyon y1 öncesinden 12 bin y1l öncesine, Holosen devresinin başlangıcına kadar geçen devre) başlangıcında belirmiştir. 1,2-0,6 milyon yıl önce yaklaşı 40 bin yıllık periyoda sahip zayıf döngüler, tekrarlama periyodu yaklaşık 100 bin y1l olan daha güçlü döngülere dönüşmüştür. $\mathrm{Bu}$ dönüşüm, Orta-Pleistosen Geçişi veya Devrimi olarak bilinir (Past Interglacials Working Group of PAGES 2016). Her buzul buzullararası döngünün küçük bir bölümü (örneğin, son 430 bin yıldaki her döngünün ortalama \% 20'si, normal olarak 10-30 bin y1lı) buzullararası dönemde geçmiştir (Jansen vd. 2007; Şekil 1).

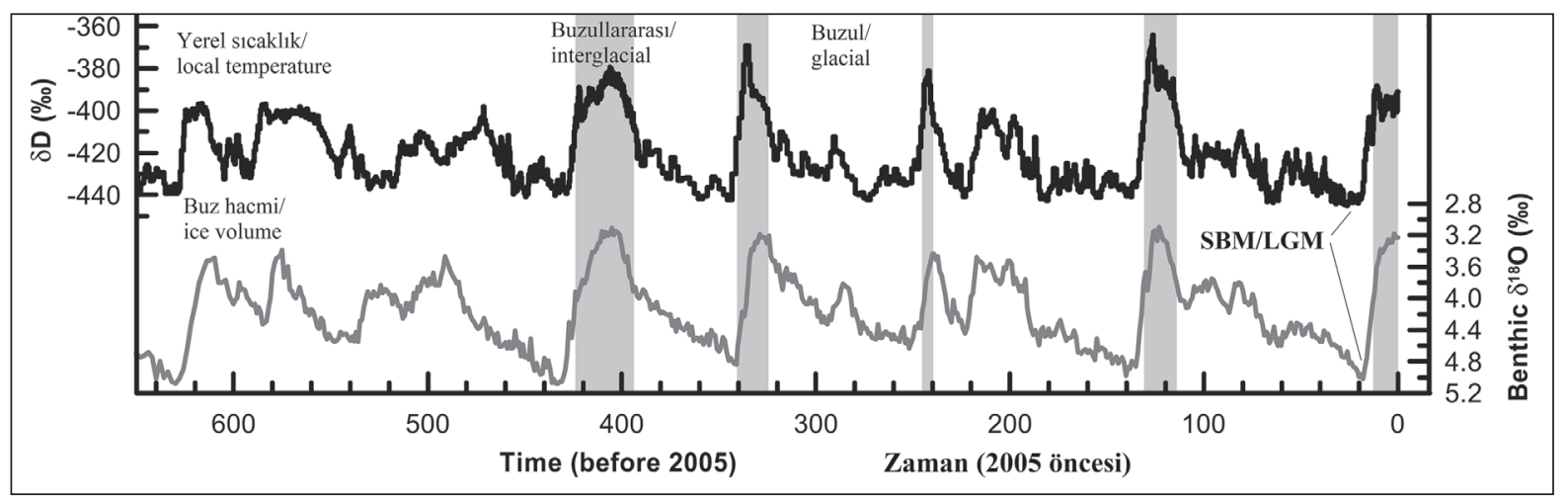

Şekil 1. Bentik $\delta^{18} \mathrm{O}$ (küresel buz hacminin bir göstergesi) ve $\delta \mathrm{D}$ (döteryum, yerel sıcaklığın bir göstergesi) duraylı izotoplarında son 650 bin yılda gözlenen değişkenlikler (Jansen vd. 2007'den değiştirilerek). SBM, Son Buzul Maksimum.

Figure 1. Variations of benthic $\delta^{18} \mathrm{O}$ (a proxy for global ice volume) and $\delta D$ (deuterium, a proxy for local temperature) stable isotopes throughout $650 \mathrm{ka}$ (from Jansen vd. 2007). LGM, the Last Glacial Maximum. 
Peki, buzul buzullar arası döngüler nasıl oluşur? Milutin Milankoviç (1879-1958) tarafından geliştirilen ve Dünya'nın hareketlerini uzun dönemli iklim değişiklikleri ile ilişkilendiren teoriye göre, dönemsellik sergileyen orbital parametreler diş merkezlilik, eğiklik ve yalpalama (Milankoviç döngüleri olarak bilinir; bkz. bilgilendirici bir simülasyon için, http://cimss. ssec.wisc.edu/wxfest/Milankovitch/earthorbit. html), atmosferin üst kısmına gelen solar radyasyonun mevsimsel ve enlemsel dağılımını değiştirir. Böylece, 65. kuzey enlem civarına yaz mevsiminde gelen solar radyasyonun minimuma ulaşması, kış boyu yağan karın yıl boyu kalmasına ve böylece kuzey yarımkürede buz tabakaları oluşturacak şekilde birikmesine neden olarak buzul dönemleri tetikler. Örneğin, 65. kuzey enleme haziran ayında gelen solar radyasyon, son buzul dönemin başlangıcında (116 \pm 1 bin yıl önce) günümüzde olduğundan $40 \mathrm{~W} / \mathrm{m}^{2}$ daha azd1 (Jansen vd. 2007).

Son buzul dönem, 115 bin y1l öncesi ile 12 bin yıl öncesi (Holosen devresinin, yani içinde bulunduğumuz buzullararası dönemin başlangıcı) arasında yaşanmıştır. $\mathrm{Bu}$ dönemin kıtasal buz tabakalarının maksimum yüzölçümüne ulaştı̆̆ 1 zamanı (18-22 bin yıl öncesi), Son Buzul Maksimum olarak bilinir (Cowie 2007). Binlerce kilometre kalınlığındaki kıtasal buz tabakaları, Son Buzul Maksimum'da Avrupa kitasinda kuzey Avrupa'nın çoğunu, İskandinavya'yı ve kuzey Britanya Adaları'nı kaplamıştır (Cowie 2007; Şekil 2). Tüm Avrupa kıtası, Son Buzul Maksimum'da günümüzden daha soğuk ve özellikle Akdeniz çevresi hariç daha kuraktı. Örneğin, yıllık ortalama sıcaklık, Son Buzul Maksimum'da günümüzden kuzey Avrupa'da $>20{ }^{\circ} \mathrm{C}$, güney Avrupa'da ise $<8{ }^{\circ} \mathrm{C}$ daha düşüktü (Şekil 3). Günümüz ile kıyaslandığında, Son Buzul Maksimum'da alışılmadık iklimsel koşullar, kuzey/kuzeydoğu Avrupa'da gözlenmiştir (Şekil 4). Yani, Son Buzul Maksimum ile günümüz arasında iklimsel koşullarda gözlenen farklılıklar, özellikle kuzey
Avrupa'da daha fazladır (Şekil 3 ve 4). Ayrıca, Son Buzul Maksimum ile günümüz arasında iklimin uzamsal/alansal yer değiştirme hızı [= iklim değişikliği velositesi (örneğin, sıcaklık için, $\left.\mathrm{km} \mathrm{y}_{1} \mathrm{l}^{-1}={ }^{\circ} \mathrm{C} \mathrm{y}_{1} 1^{-1} /{ }^{\circ} \mathrm{C} \mathrm{km}{ }^{-1}\right)$ - iklimin y1lda kaç $\mathrm{km}$ yer değiştireceğini ve böylece türlerin yer değiştirirken ne kadar hızlı olmaları gerektiğini ifade eder; Hamann vd. 2015], kuzey Avrupa'da daha yüksektir (Sandel vd. 2011). Böylece, güney Avrupa (İberya, İtalya, Balkanlar ve Anadolu), genel olarak buzul buzullararası döngülerden daha az etkilenmiştir.

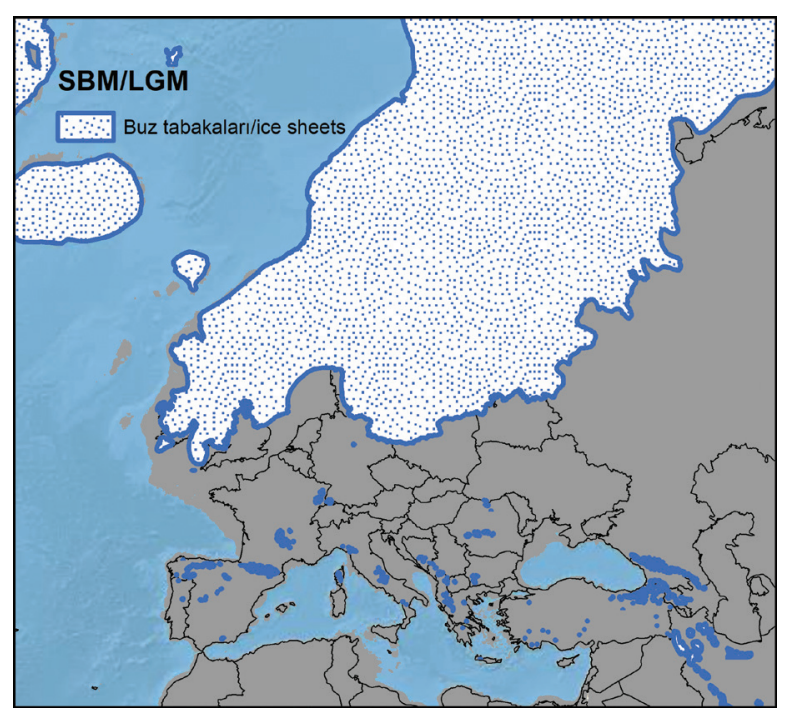

Şekil 2. Son Buzul Maksimum (SBM)'da Avrupa kitasında buz tabakaları ve buzullar (Ehlers vd. 2011'e dayanarak çizilmiştir). Karasal alanlar, Son Buzul Maksimum ile günümüz arasında farklıdır.

Figure 2. Ice sheets and glaciers in Europe in the Last Glacial Maximum (LGM) (drawn based on Ehlers $v d$. 2011). Land areas differ between the Last Glacial Maximum and the present.

Son Buzul Maksimum'da kuzeydeki alanlar kıtasal buz tabakaları ile kaplanırken, güney Avrupa'daki Akdeniz'i çevreleyen dağlarda da buzullar gelişmiştir (Hughes and Woodward 2017). Son Buzul Maksimum'da günümüzden daha soğuk olan ve (yağış genel olarak değişmez iken) kuzeyi biraz daha az ve güneyi ise daha fazla yağış 
alan Anadolu'da (Şekil 5, ayrıca bkz. Şekil 3 ve paralel bir paleoiklimsel yorum için, Sarıkaya and Çiner 2015) ise üç bölgede buzullar oluşmuştur: Toros Dağları, Doğu Karadeniz Dağları ve dağınık ve tekil olarak bulunan yüksek dağlar ve volkanlar (Sarıkaya vd. 2011; Sarıkaya and Çiner 2015, 2017; Akçar vd. 2017; Şekil 6, ayrıca bkz. Şekil 2). Bu buzullar, maksimum pozisyonlarına ortalama $20.9 \pm 1.5$ bin y1l önce ulaşmıştır. Daimi kar sınırı ise, günümüze göre, yaklaşık 1000 metre kadar düşmüştür (Akçar vd. 2017). Son Buzul Maksimum'da Anadolu'da buzulların geliştiği bilinen dağların coğrafi dağılımı, iklimsel değişkenler (özellikle yaz sıcaklığı) ile yüksek bir doğrulukta kestirilebilmektedir (Şekil 6). Bu dağların iklimsel koşullar açısından sergilediği en önemli özellikler, yaz sıcaklığının düşük ve yaz sıcaklığı ile kış yağışı arasında pozitif bir ilişkinin var olmasıdır (Şekil 7). Yaz sıcaklığının düşük olması, kış boyu yağan karın yıl boyu kalmasına ve böylece buzulları oluşturacak şekilde birikmesine neden olur. Ancak kış boyu yağan karın yıl boyu kalması ve böylece buzulları oluşturabilmesi, yaz sıcaklığının daha yüksek olduğu dağlarda kış yağışının daha fazla olması ile mümkündür. Örneğin, Son Buzul Maksimum'da yaz sıcaklığının daha yüksek olduğu güneybatı Anadolu dağlarında kış yağışı da daha fazladır (Şekil 7).

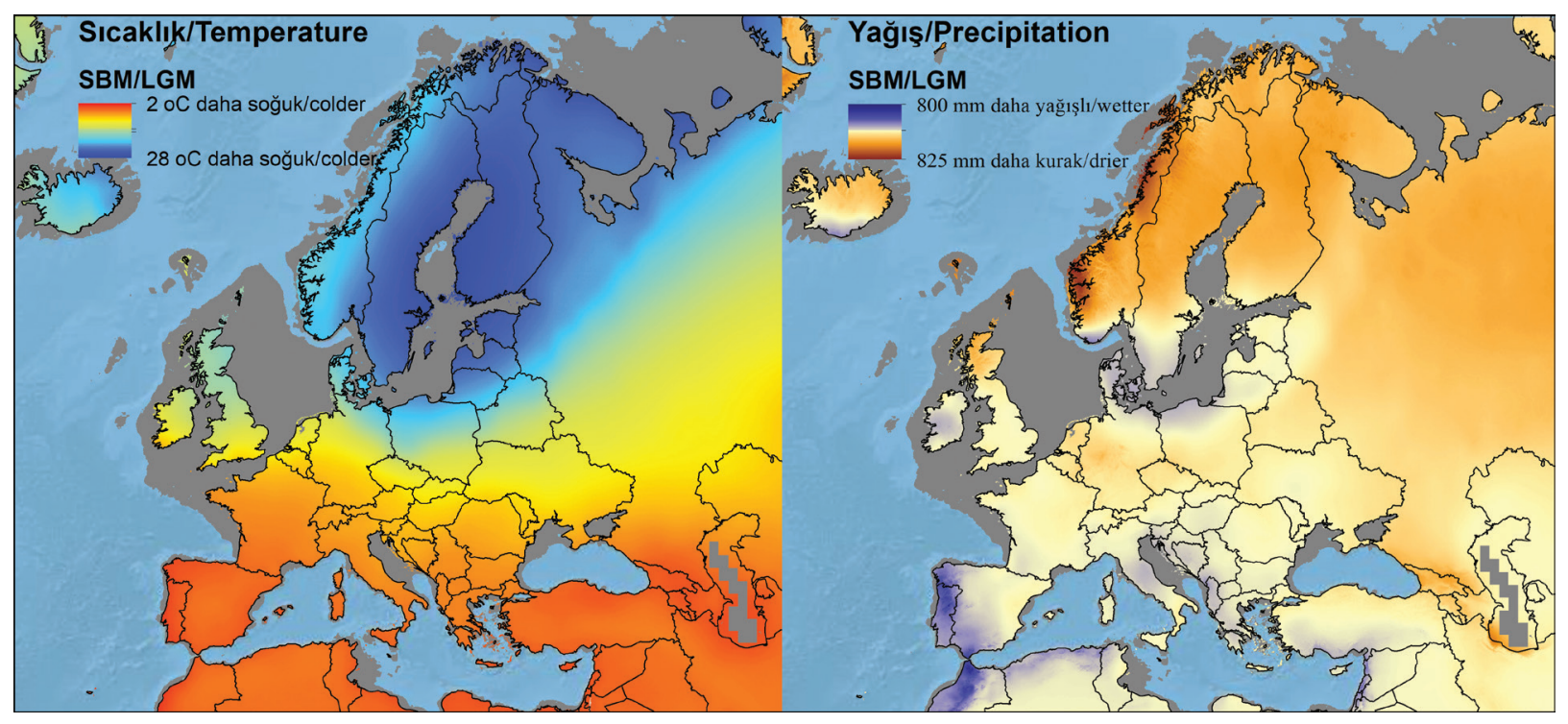

Şekil 3. Son Buzul Maksimum (SBM) ile günümüz arasında gözlenen iklimsel farklılıklar. İklimsel veri, yıllık ortalama sıcaklığı ve yağışı içerir ve WorldClim veri tabanından (versiyon 1.4, www.worldclim.org) elde edilmiştir. Son Buzul Maksimum verisi, üç farklı küresel iklim modelinin ortalamasıdır: CCSM4, MIROC-ESM ve MPIESM-P. Karasal alanlar, Son Buzul Maksimum ile günümüz arasında farklıdır.

Figure 3. Climatic differences between the Last Glacial Maximum (LGM) and the present. Climatic data include annual mean temperature and precipitation, and were downloaded from the WorldClim database (version 1.4, www. worldclim.org). Last Glacial Maximum data are the average of three different global climate models: CCSM4, MIROC-ESM ve MPI-ESM-P. Land areas differ between the Last Glacial Maximum and the present. 


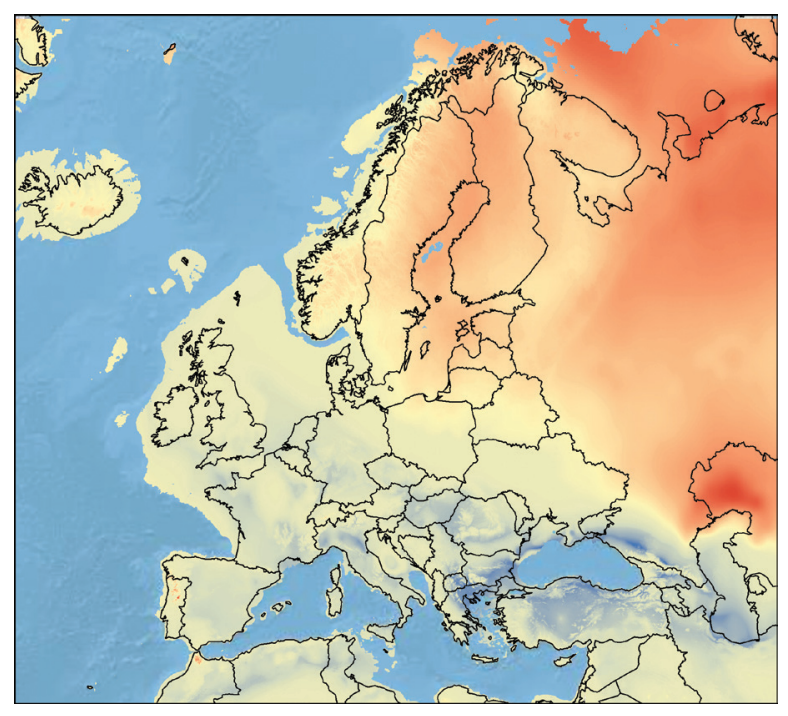

Şekil 4. Günümüz ile kıyaslandığında, Son Buzul Maksimum'da alışılmadık iklimsel koşulların gözlendiği alanlar (kırmızı). Sonuçlar, çok değişkenli çevresel benzerlik yüzeyi analizi ile elde edilmiştir (Elith vd. 2010). İklimsel veri, yıllık ortalama sıcaklığı, sıcaklık mevsimselliğini, yaz ve kış ortalama sıcaklıklarını, yıllık yağışı, yağış mevsimselliğini ve yaz ve kış yağışlarını içerir ve WorldClim veri tabanından (versiyon 1.4, www.worldclim.org) elde edilmiştir. Son Buzul Maksimum verisi, CCSM4 küresel iklim modeline dayanır. Diğer küresel iklim modelleri, benzer sonuçlar vermiştir. Karasal alanlar, Son Buzul Maksimum ile günümüz arasında farklıdır.

Figure 4. Areas (red) of novel climatic conditions in the Last Glacial Maximum, compared with the present. The results were obtained by the multivariate environmental similarity surface analysis (Elith vd. 2010). Climatic data include annual mean temperature, temperature seasonality, summer and winter mean temperatures, annual precipitation, precipitation seasonality, and summer and winter precipitations, and were downloaded from the WorldClim database (version 1.4, www.worldclim.org). Last Glacial Maximum data are based on the CCSM4 global climate model. The other global climate models gave similar results. Land areas differ between the Last Glacial Maximum and the present.

\section{GEÇ KUVATERNER İKLIM DEĞİŞIKLIKLERİ VE COĞRAFİ DAĞILIMLARDAKİ DEĞİŞIKLIKLER}

Türler, buzul buzullararası döngülere eşlik eden güçlü iklimsel dalgalanmalara yerlerini (yani, coğrafi dağılımlarını) değiştirerek ve/veya değişen çevresel koşullara uyum/uyarlanma (= doğal seçilim yoluyla evrimleşen ve bireylerin uyum gücünü arttıran karakter veya karakterin belirli bir durumu; Gür 2016a) yoluyla veya yok olarak cevap verir (Jansson and Dynesius 2002). O dönem fosil balıklar konusunda dünyanın önde gelen uzmanı olan Louis Agassiz (1807-1873), 1840 yılında yayınladığı ve Buzul Çağı (Ice Age veya Eiszeit) fikrini (ki bu kavram, kendisine bir meslektaş1, botanikçi Karl Schimper tarafindan önerilmiştir) tartıştığı 'Buzul Araştırmaları' (Études sur les glaciers, Studies of glaciers) kitabında bunu şöyle tasvir etmiştir (Gribbin 2002; Gribbin and Gribbin 2002):

"Bu dev buz örtülerinin gelişimi, yeryüzündeki bütün organik yaşamın yıkımına sebep olmuş olsa gerektir. Daha önce tropik bitkilerle kaplı ve dev fil sürüleri, kocaman hipopotamlar ve devasa etoburlara ev sahipliği yapan Avrupa topraklar birdenbire göz alabildiğince yayılmış buzla kapl düzlükler, göller, denizler ve platoların altına gömüldü. Onu ölümün sessizliği izledi...",

Coğrafi dağılımlardaki değişiklikler, bu cevaplardan en çarpıcı ve en iyi belgelenmiş olanıdır. Charles Robert Darwin (1809-1882), 1859 yılında yayınlanan 'Doğal Seçilim Yoluyla Türlerin Kökeni Üzerine veya Yaşam Savaşında Avantajlı Irklarin Korunmast' (On the Origin of Species by Means of Natural Selection, or the Preservation of Favoured Races in the Struggle for Life) adlı kitabında buna şöyle değinmiştir (Darwin 1859): 


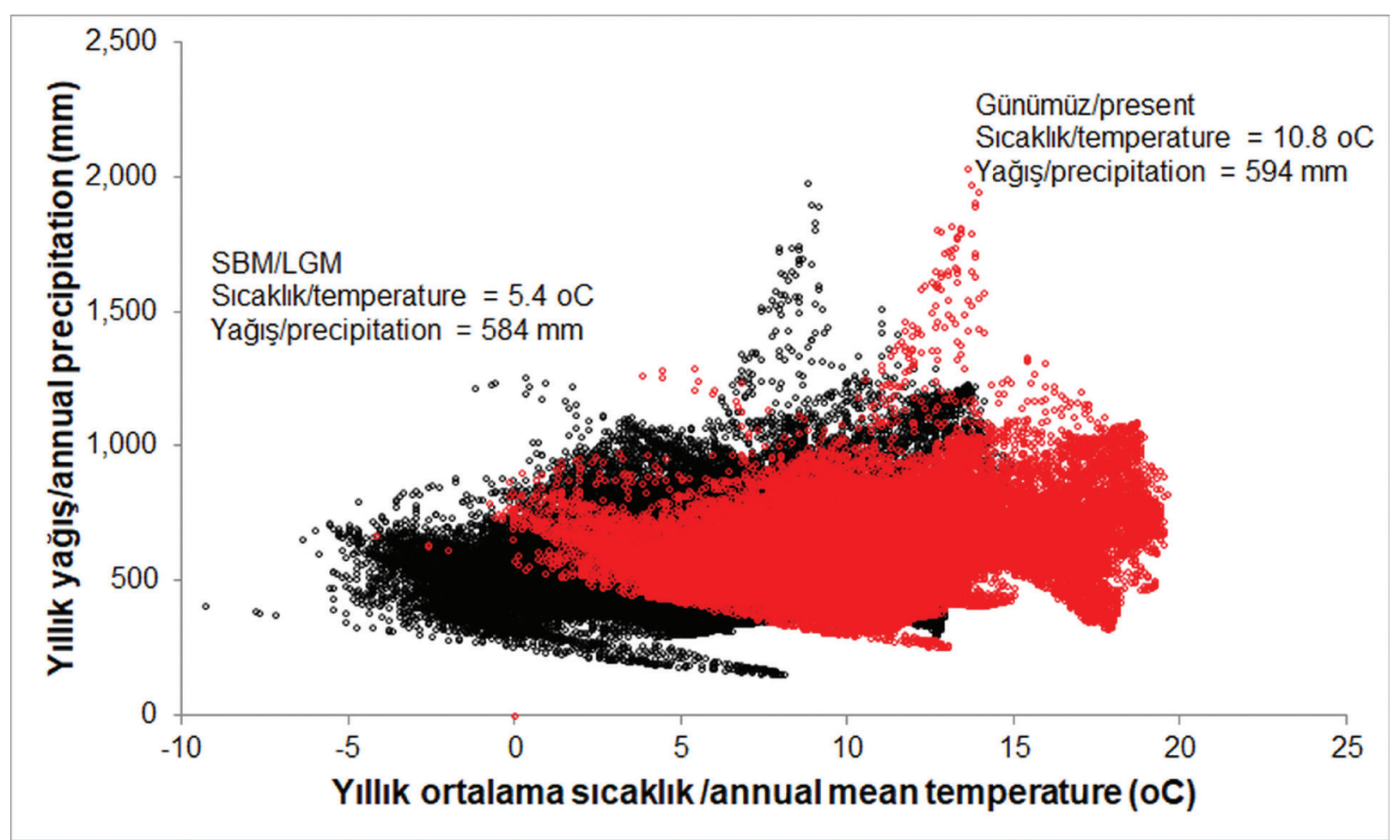

Şekil 5. Son Buzul Maksimum (SBM, siyah noktalar) ve günümüzde (kırmızı noktalar) Anadolu ve yakın çevresinin iklimsel uzamı (bkz. Şekil 6). İklimsel veri, yıllık ortalama sıcaklığı ve yağışı içerir ve WorldClim veri tabanından (versiyon 1.4, www.worldclim.org) elde edilmiştir. Bu veri, CCSM4 küresel iklim modeline dayanır.

Figure 5. Climatic space of Anatolia and surrounding areas in the Last Glacial Maximum (LGM, black points) and the present (red points) (see Figure 6). Climatic data include annual mean temperature and precipitation, and were downloaded from the WorldClim database (version 1.4, www.worldclim.org). These data are based on the CCSM4 global climate model.

“... Soğuğun gücünü hissettirmesiyle ve daha güney kuşakların gitgide arktik canlılara daha uygun ve önceki daha lliman sakinlere daha uygunsuz duruma gelmesiyle, ilıman sakinler yerlerini arktik üretimlere biracaktır. Daha ılıman kesimlerin sakinleri, bariyerler yoluyla durdurulmadıkları sürece güneye doğru ilerleyecek, değilse yok olup gidecektir. Dağlar kar ve buzla kaplanacak ve bu dağların daha önceki alpin sakinleri ovalara inecektir. Soğuk had safhaya ulaştığında, Avrupa'nın orta kesimlerini, güneyde Alplere ve Pirenelere, hatta İspanya'nın iç kesimlerine kadar kaplayan tek biçimli bir arktik fauna ve flora ortaya çıkacaktır. ...
Sicakliğın artmasıly arktik formlar kuzeye doğru çekilecek, daha ılıman kesimlerin üretimleri de hızla onları izleyecektir. Dağların eteklerindeki karlar eridikçe, arktik formlar açılan ve buzu çözülen toprakları ele geçirecek ve kardeşleri kuzeye olan yolculuklarını sürdürürken, onlar sicaklı̆̆ın artmasıyla gitgide daha yükseğe çıkacaktır. ..."

Bilim tarihinin en önemli kitaplarından biri olan bu kitap, iki temel kurama sahiptir: (1) Değişerek türeme. Bu kuram, yaşayan ve soyu tükenen tüm türlerin ortak bir kökene sahip olduğunu belirtir. (2) Doğal seçilim. Bu kuram, 'Türlerin Kökeni'nin gerçek katkısıdır; 
değişerek türemeden sorumlu mekanizmayla ilgilidir ve Lamark'ın bireysel organizmaların değiştiği transformasyonal kuramından farklı olarak popülasyonların değiştiği varyasyonal bir kuramdır (Gür 2016a).

Türler, buzul buzullararası döngülere cevap olarak, coğrafi dağılımlarını döngüsel bir şekilde daraltır ve genişletir. Bir türün bir buzul buzullararası döngü boyunca dağılım gösterdiği coğrafi bölge veya bölgeler (ki bu bölgeler, türün coğrafi dağılımındaki maksimum daralmayı temsil eder), Kuvaterner sığınakları olarak tanımlanır. Genel olarak üç tip sığınaktan bahsedilebilir: buzul sığınakları, buzullararası sığınaklar ve okyanusalkitasal gradiyent (Stewart vd. 2010; bkz. alternatif bir sınıflandırma için, Bennett and Provan 2008). $\mathrm{Bu}$ sığınak tipleri, genel olarak türlerin enlemsel (ilk iki tip) ve boylamsal hareketine vurgu yapar. Bir diğer sığınak tipi, rakımsal hareketlerdir ve türlerin rakımsal hareketine vurgu yapar (Bennett and Provan 2008; Stewart vd. 2010). Ancak, bu tür sınıflandırmaların (ister coğrafi dağılımlardaki değişiklikler, ister genel olarak biyolojik bilimlerdeki diğer varyasyonlar açısından olsun) örüntüleri anlamamızı kolaylaştırdığı, ancak aşırı bir basitleştirme olduğu unutulmamalıdır!

Buzul sığınaklar, 1lıman kuşak türlerinin (örneğin, sar1 boyunlu orman faresi, Apodemus sylvaticus; su sıçanları, Arvicola spp.; çayır çekirgesi, Chorthippus parallelus; küçük beyaz dişli böcekçil, Crocidura suaveolens; kirpiler, Erinaceus sp.; meşeler, Quercus spp.; semenderler, Triturus spp.; bozay1, Ursus arctos) coğrafi dağılımlarının buzul dönemlerde genel olarak güneydeki coğrafi bölgelere (güney sığınakları) daralmasını ifade eder. Bu sığınaklar, genel olarak buzul buzullararası döngülerden daha az etkilenen güney Avrupa'da (İberya, İtalya, Balkanlar ve Anadolu) konumlanır. Ilıman kuşak türleri, coğrafi dağılımlarını buzullararası dönemlerde buzul sığınaklardan başlayarak kuzey Avrupa'ya doğru genişletir (Stewart vd. 2010). Ancak bu buzul sığınakların her zaman bir bütün olarak tek bir sığınak gibi davrandığı düşünülmemelidir. Akdeniz'e doğru uzanan bu yarımadalar, kendi içinde özellikle endemik ve/veya yerel türler için birden fazla sığınak içerebilir. Bu durum, coğrafi dağılımların döngüsel bir şekilde daralması ve genişlemesinin bu sığınaklar içinde de gerçekleştiğini gösterir ve 'sığınaklar içinde sığınaklar' modeli olarak bilinir (Gómez and Lunt 2007). Ayrıca, buzul sığınakların bazı 1lıman kuşak türleri (örneğin, altın otu, Asplenium ceterach; parmaksaz, Carex digitata; kırmızı sırtlı fare, Clethrionomys glareolus; orman böcekçili, Sorex araneus) için beklenenden daha kuzeyde olduğu bilinmektedir (kriptik kuzey sığınakları; Stewart vd. 2010). Burada belirtilmesi gereken önemli bir nokta, diğer buzul sığınaklarda olduğu gibi, Avrupa'nın biyolojik çeşitliliğinin şekillenmesi açısından Anadolu'nun buzul sığınak rolünün daha iyi anlaşılması gerektiğidir. Bu tür çalışmalar, son yıllarda yaygınlaşmaktadır (örneğin, Rokas vd. 2003; Koch vd. 2006; Ansell vd. 2011; Korkmaz vd. 2014; Perktaş vd. 2015a; Bilgin vd. 2016).

Buzullararası sığınaklar, soğuğa uyum sağlayan türlerin (örneğin, kutup tilkisi, Alopex lagopus; lemmingler, Dicrostonyx spp. ve Lemmus spp.; misk sı̆̆ır1, Ovibus moschatus; Ren geyiği, Rangifer tarandus) coğrafi dağılımlarının buzullararası dönemlerde genel olarak kuzeydeki coğrafi bölgelere (polar-kuzey sığınakları) daralmasını ifade eder. Bu sığınaklar, genel olarak Avrasya'nın kuzeyinde konumlanır. Soğuğa uyum sağlayan türler, coğrafi dağılımlarını buzul dönemlerde buzullararası sığınaklardan başlayarak genişletir. Ayrıca, buzullararası sı ğınakların soğuğa uyum sağlayan bazı türler (örneğin, bodur huş, Betula nana; bir mübarekotu türü, Dryas octopetala; bir kınkanatlı böcek türü, Helophorus lapponicus; kaya kar tavuğu, Lagopus mutus; kutup tavşan1, Lepus timidus) için beklenenden daha güneyde olduğu bilinmektedir (kriptik güney sığınakları; Stewart vd. 2010). 
Türlerin buzul buzullararası döngülere cevabında bugüne kadar sıklıkla göz ard1 edilen bir diğer biyocoğrafi boyut, okyanusalkıtasal gradiyenttir. Okyanusal daha nemli ve daha az mevsimsel iklime, kıtasal ise daha kurak ve mevsimsel iklime uyumu belirtir. Bu gradiyent, kuzey ve güney sığınakların enlemsel konumlanmasının tersine, siklıkla boylamsal olarak konumlanır. Böylece, kıtasal uyum sağlayan türlerin coğrafi dağılımlarının buzullararası dönemlerde genel olarak kıtanın iç kesimlerine doğru (kıtasal sığınaklar), okyanusal uyum sağlayan türlerin ise coğrafi dağılımlarının buzul dönemlerde genel olarak kıtanın dış kısımlarına doğru (okyanusal sığınaklar) daralması beklenir. Kıtasal ve okyanusal uyum sağlayan türler, coğrafi dağılımlarını sırasıyla buzul ve buzullararası dönemlerde kıtasal ve okyanusal sığınaklardan başlayarak genişletir. Ayrıca, bazı 1lıman kuşak türleri için kriptik kuzey sığınaklarına ve bazı soğuğa uyum sağlayan türler için kriptik güney sığınaklarına benzer bir olgu, boylamsal bir eksende gerçekleşir [örneğin, kıtasal sığınakların kıtasal uyum sağlayan bazı türler (örneğin, yalancı iğde, Hippophae rhamnoides; güney huş faresi, Sicista subtilis) için beklenenden daha batıda olması gibi; Stewart vd. 2010]. Stewart vd. (2010), fosil kayıtları ve modern coğrafi dağılımların karşılaştırılmasına dayanarak, bazı Avrasya memeli türlerinin (örneğin, yer sincapları, Spermophilus spp.; bozkır antilopu, Saiga tatarica; 1slıklı veya cüce tavşanlar, Ochotona spp.) bugün Palaeartik'te daha sinırlı bir kitasal dağılıma sahipken, son buzul dönemde Britanya Adaları'na kadar uzanan daha geniş bir dağılıma sahip olduğunu belirtmiş; ancak bu kıtasal örüntü ile ilgili herhangi bir filocoğrafi çalışmanın olmadığını da eklemiştir (Gür 2013, bu açıdan ilk çalışmadır; bkz. aşağıya). Aynı şekilde, okyanusal örüntü ile ilgili de iyi bir örnek bilmediklerini belirtmişlerdir.
Rakımsal hareketler, özellikle dağ türlerinin coğrafi dağılımlarının buzul dönemlerde düşük rakımlara, buzullararası dönemlerde ise yüksek rakımlara doğru değişmesini ifade eder (Bennett and Provan 2008; Stewart vd. 2010).

Aslında bu sığınak tipleri, türlerin buzul buzullararası döngülere eşlik eden iklim değişikliklerine genel olarak nasıl cevap verdiğini (coğrafi dağılımın ne zaman ve hangi coğrafi bölgeye doğru daraldığını ve ardından genişlediğini) tanımlar. Bu cevap, türlerin coğrafi genetik çeşitlilik örüntüsünü şekillendiren ana etkenlerden biridir: genel olarak genetik çeşitlilik sığınak alanlarda daha yüksek, bu sığınak alanlardan son zamanlarda kolonize edilen bölgelerde ise daha düşüktür. Örneğin, genetik çeşitlilik, 1lıman kuşak türleri için genel olarak güney Avrupa'da kuzeyde olduğundan daha yüksektir. Bu durum, 'güney zenginliği ve kuzey saflığı' olarak bilinir (Hewitt 2000, 2004a,b) ve aynı zamanda güney Avrupa'nın yüksek biyolojik çeşitliliğini ve endemizmini (Sandel vd. 2011) de açıklar (bkz. aşağıya).

\section{COĞRAFİ DAĞILIMLARDAKİ DEĞİŞİKLIKKLEİ ÇALIŞMAK}

Türlerin buzul buzullararası döngülere eşlik eden iklim değişikliklerinenasıl cevapverdiğini anlamak için, ekolojik niş modellemesi, son zamanlarda biyocoğrafi çalışmalarda moleküler filocoğrafya ile birlikte yaygın olarak kullanılmaktadır (Perktaş and Gür 2015). Moleküler filocoğrafya, yakın ilişkili türler arasında veya tür içinde genetik varyasyonun dağılımını etkileyen süreçleri anlamaya çalışır. Bu yaklaşım, nötral genetik varyasyon örüntüsünün türün demografik tarihi ile ilgili bilgi vermesi temeline dayanır. Demografik tarih, populasyon büyüklüğündeki dalgalanmalar, popülasyon ayrılmaları (vikaryant olaylar ve/veya migrasyon ile farklılaşma) gibi genetik varyasyon 
örüntüsünü üreten demografik olaylardan oluşur (Avise vd. 1987; Avise 2000).

Ekolojik niş modellemesi, bir türün coğrafi dağılımını tahmin etmek için, ilk olarak o tür için uygun çevresel koşulları ve daha sonra bu çevresel koşulların alansal dağılımını belirler. Ancak bir türün uygun çevresel koşullara sahip tüm coğrafi yerlerde dağılmasını engelleyen birçok neden (örneğin, dispersali sınırlayan coğrafi bariyerler, diğer türler ile rekabet) vardır. Yine de, bu yaklaşım, değerli biyocoğrafi bilgiler sunar. Böylece, ekolojik niş modellemesi, tür dağılım verisini (coğrafi koordinat cinsinden türlerin gözlendiği yerler) bu yerlerin çevresel ve/ veya alansal özellikleri [coğrafi bilgi sistemine dayalı bir yaklaşım kullanılarak elde edilen çok sayıda çevresel (örneğin, iklimsel) ve/veya alansal (örneğin, rakım) değişken] ile ilişkilendirerek, türlerin coğrafi dağılımını tahminleyen [coğrafi uzamdaki tür dağılım verisinden ve çevresel veriden oluşturulan ve çevresel uzamda $n$ boyutlu bir hiperhacim olarak düşünülen ekolojik nişi (Hutchinson 1957) coğrafi uzama taşıyan] bir model oluşturur. $\mathrm{Bu}$ model, türlerin geçmişteki veya gelecekteki coğrafi dağılımlarını tahmin etmek için, küresel iklim modellerine dayanarak yeniden oluşturulan geçmiş ve/veya öngörülen gelecek iklim verilerine uygulanır (Peterson vd. 2011).
Ekolojik niş modellemesi için gereken veri, tür dağ 11 ım verisi (coğrafi koordinat cinsinden türlerin sadece gözlendiği veya hem gözlendiği hem de gözlenmediği yerler) ve çevresel (örneğin, biyoiklimsel) veridir. Tür dağılım verisi, tür dağılım veri tabanlarından elde edilebilir (bkz. Richards vd. 2007). Örneğin, Global Biodiversity Information Facility (www.gbif.org), yaklaşık 838 milyon ( \% 90’1 coğrafi koordinat cinsinden) dağılım kaydının serbest kullanımına izin veren bir veri tabanıdır (siteye erişim tarihi, 16 Eylül 2017). Çevresel veri, iklim veri tabanlarından elde edilebilir (bkz. Richards vd. 2007). Örneğin, WorldClim (www.worldclim.org), en s1k kullanılan ve tüm dünya için 19 değişkenden oluşan biyoiklimsel verinin serbest kullanımına izin veren bir veri tabanıdır. Bu veri, geçmiş [son buzullararası dönem ( 140-120 bin y1l önce), Son Buzul Maksimum ( 22 bin y1l önce) ve Orta Holosen ( $\sim 6$ bin y1l önce)], günümüz $(\sim 1960$ 1990) ve gelecek (2041-2060, 2061-2080) için mevcuttur.

Ekolojik niş modellemesi, aynı zamanda tür dağılım ve çevresel verilere ek olarak, modelleme tekniklerine (algoritmalara) ihtiyaç duyar. Bu algoritmaların (bkz. Richards vd. 2007) en etkinlerinden biri, MAXENT yazılımındaki (Phillips vd. 2006; Elith vd. 2011) maksimum entropi makine öğrenme algoritmasıdır (Elith vd. 2006). 


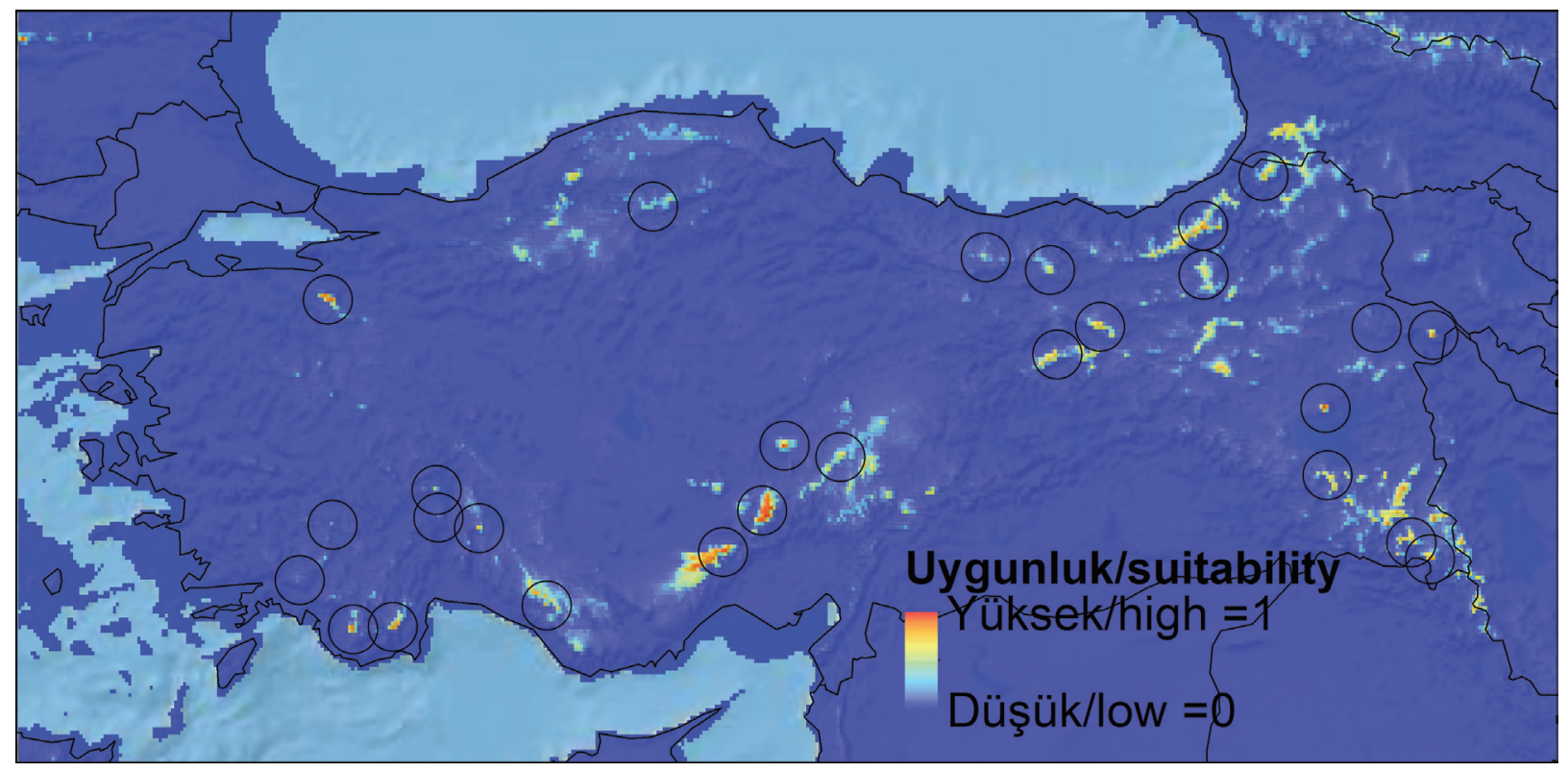

Şekil 6. Son Buzul Maksimum iklimsel koşulları altında Anadolu'da buzul gelişimi için iklimsel olarak uygun alanlar. Sonuçlar, ekolojik niş modellemesi yaklaşımı kullanılarak, MAXENT yazılımındaki (versiyon 3.3.3k) maksimum entropi makine öğrenme algoritması ile elde edilmiştir (bkz. ana metin). Buzulların coğrafi dağılımı (çemberler, $\mathrm{n}$ = 27), Sarıkaya vd. (2011)'den alınmıştır. İklimsel veri, yaz ve kış ortalama sıcaklıklarını ve yağışlarını içerir ve WorldClim veri tabanından (versiyon 1.4, www.worldclim.org) elde edilmiştir. Bu veri, üç farklı küresel iklim modeline dayanır: CCSM4, MIROC-ESM ve MPI-ESM-P. Karasal alanlar, Son Buzul Maksimum ile günümüz arasinda farklidır.

Figure 6. Climatically suitable areas for development of glaciers in Anatolia under Last Glacial Maximum climatic conditions. The results were obtained by the maximum entropy machine learning algorithm in the software MaxEnt (version 3.3.3k), using ecological niche modelling approach (see main text). The geographical distribution of glaciers (circles, $n=27$ ) is from Sarlkaya vd. (2011). Climatic data include summer and winter mean temperatures and precipitations, and were downloaded from the WorldClim database (version 1.4, www.worldclim.org). These data are based on three different global climate models: CCSM4, MIROC-ESM ve MPI-ESM-P. Land areas differ between the Last Glacial Maximum and the present. 


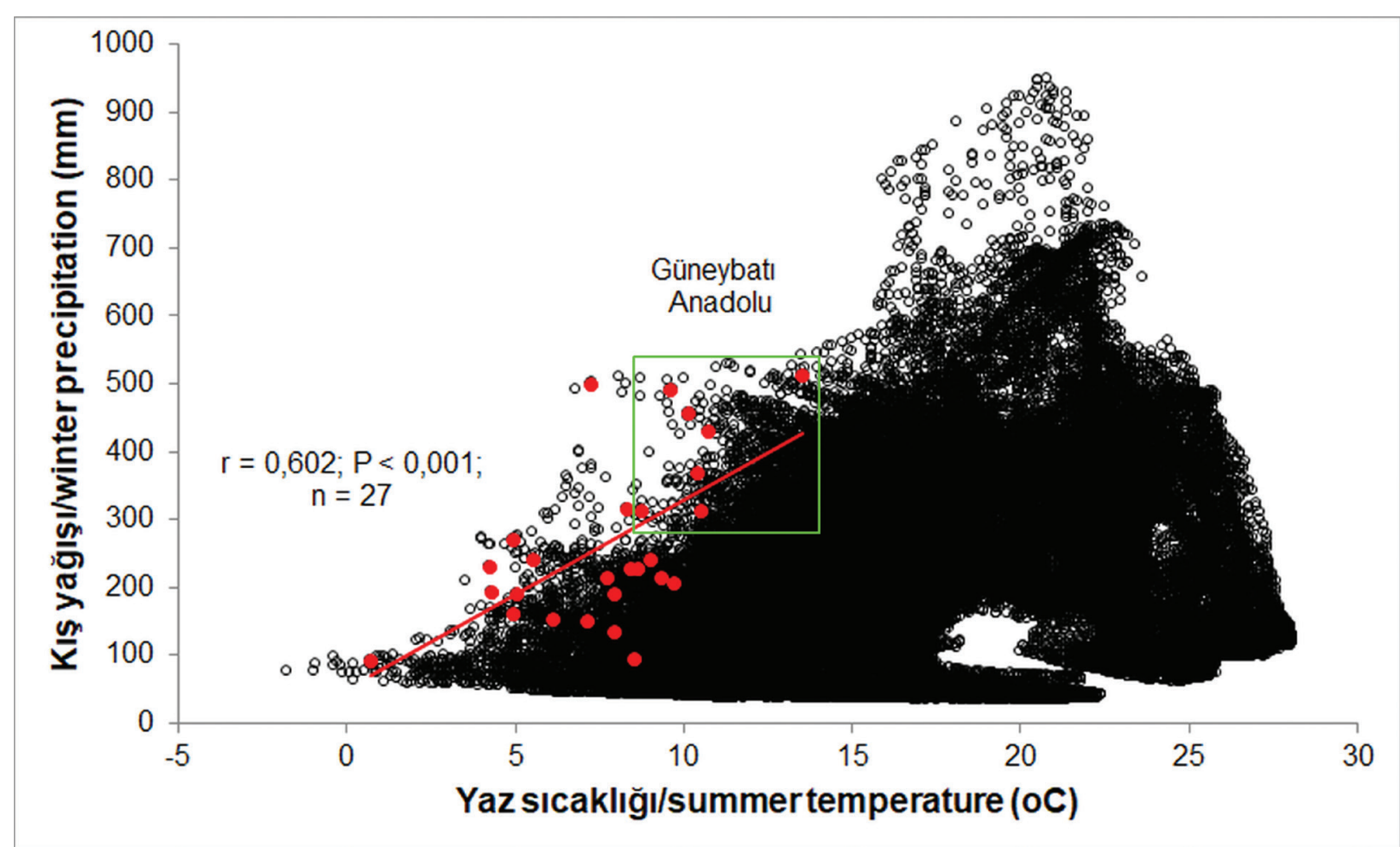

Şekil 7. Son Buzul Maksimum'da Anadolu ve yakın çevresinin (siyah noktalar) ve bu bölgedeki buzulların geliştiği bilinen dağların (kırmızı noktalar) iklimsel uzamı (bkz. Şekil 6). İklimsel veri, yaz ortalama sıcaklığını ve kış yağışını içerir ve WorldClim veri tabanından (versiyon 1.4, www.worldclim.org) elde edilmiştir. Bu veri, CCSM4 küresel iklim modeline dayanır.

Figure 7. Climatic space of Anatolia and surrounding areas (black points) and mountains (red points) in which glaciers were formed in this region (see Figure 6). Climatic data include summer mean temperature and winter precipitation, and were downloaded from the WorldClim database (version 1.4, www.worldclim.org). These data are based on the CCSM4 global climate model.

\section{GEÇ KUVATERNER İKLIMM \\ DEĞİŞIKLİKLERİ VE ANADOLU'NUN BIYYOLOJIKK ÇEŞITLILİĞİ}

Bir bölge, biyolojik çeşitlilik sıcak noktası olarak tanımlanabilmesi için, iki katı ölçütü sağlamalıdır:

(1) En az 1500 endemik damarlı bitki türüne ev sahipliği yapmalı; diğer bir deyişle, yeri doldurulamaz, eşsiz olmalıdır! (2) Özgün doğal vejetasyonunun en fazla \%30'una sahip (yani, en az \%70'ini kaybetmiş); diğer bir deyişle, tehdit altında olmalıdır! Dünyada bu ölçütleri sağlayan 36 biyolojik çeşitlilik sıcak noktası vardır. Bu sıcak noktalar, yeryüzünün sadece \%2.3'ünü kaplar, ancak endemik bitki türlerinin yarısından fazlasına, iki yaşamlı, sürüngen, kuş ve memeli türlerinin ise yaklaşık \%43'üne ev sahipliği yapar (Conservation International 2017).

Anadolu, jeolojik olarak Alp-Himalaya orojenik kuşağında yer alır (Şengör and Yılmaz 1981) ve dünyadaki 36 biyolojik çeşitlilik sıcak noktasından üçünün karşılaştığ1 ve etkileştiği biyocoğrafi olarak ilginç, ancak çok iyi anlaşılmamış bir bölgedir. Bu sıcak noktalar şunlardır: Akdeniz Havzası, İran-Anadolu ve Kafkasya biyolojik çeşitlilik sıcak noktaları (Conservation International 2017; Şekil 8). Yani, Anadolu, yüksek bir biyolojik çeşitliliğe ve endemizme sahiptir, ancak özgün doğal 
vejetasyonunun çoğunu kaybetmiştir. Diğer bir deyişle, Anadolu, sahip olduğu biyolojik çeşitlilik açısından yeri doldurulamaz, ancak zaten özgün doğal vejetasyonunun çoğunu kaybetmiş, yoğun tehdit altında olan bir bölgedir. Anadolu'nun bu yüksek biyolojik çeşitliliği ve endemizmi, belli ölçüde Avrupa, Orta Doğu, İç Asya ve Afrika'nın bağlantı noktasındaki konumu ve geçmişteki ve günümüzdeki jeolojik ve iklimsel dinamikler ile ilişkilidir (Şekercioğlu vd. 2011; Tavşanoğlu 2016; Gür 2016b; 2017; ayrıca bkz. aşağıya). kendi çalışmalarımızdan birkaç örnek verilecektir. $\mathrm{Bu}$ çalışmalarda, ekolojik niş modellemesi ve moleküler filocoğrafya yaklaşımları birlikte kullanılmıştır. Ancak bu yazıda, anlaşılacağı gibi, coğrafi dağ 1 lımlardaki değişiklikleri örneklemek açısından sadece ekolojik niş modellemesi sonuçlarına kısaca değinilecektir. Burada belirtilmesi gereken önemli bir nokta, her iki yaklaşımın sonuçlarının uyum içinde olduğudur (bkz. Gür 2013, 2016c,d; Perktaş vd. 2015a,b; Perktaş 2017; Gür vd. 2017).

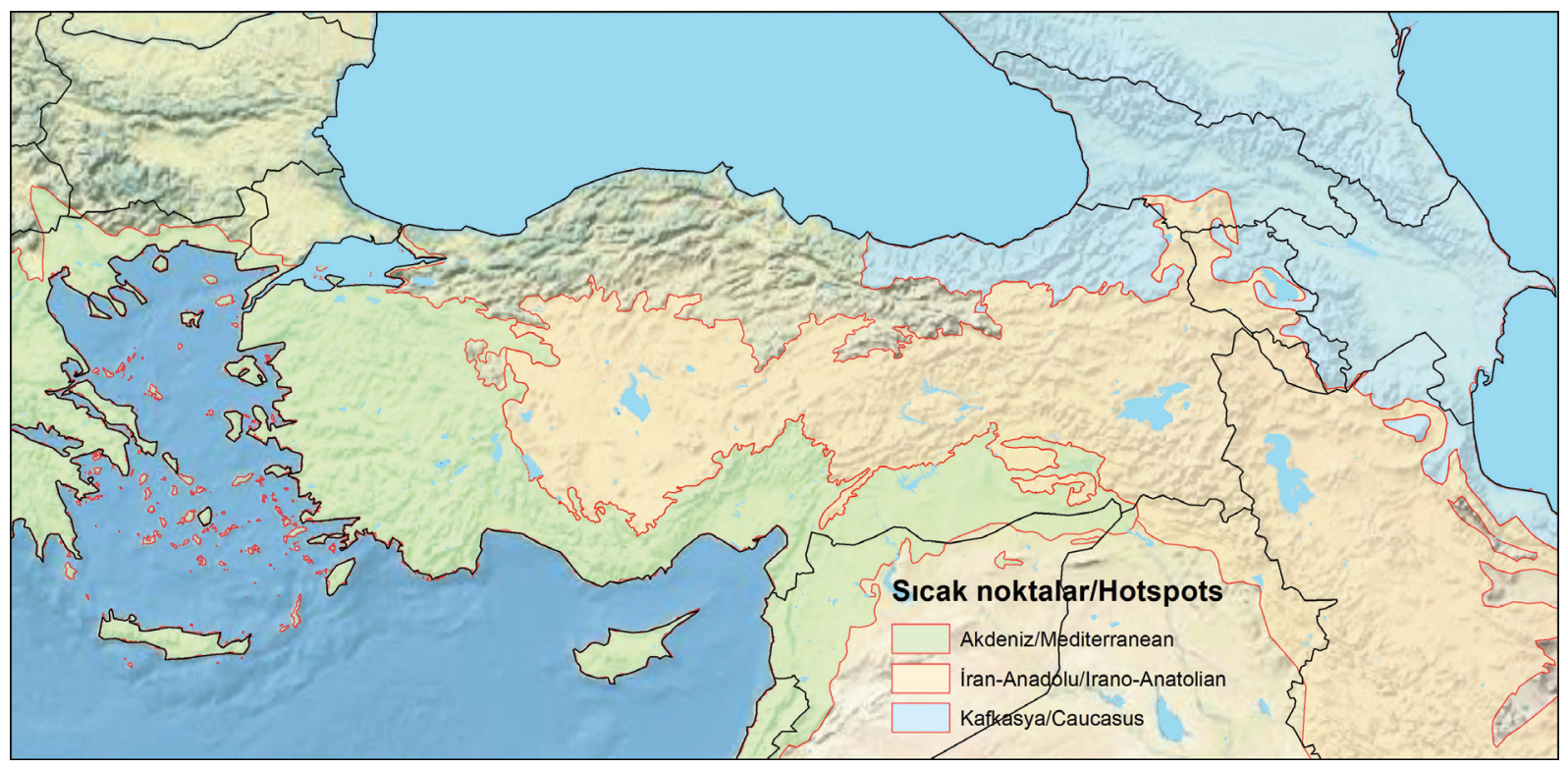

Şekil 8. Anadolu'da biyolojik çeşitlilik sıcak noktaları (Conservation International 2017'ye dayanarak çizilmiştir).

Figure 8. Biodiversity hotspots in Anatolia (drawn based on Conservation International 2017).

Anadolu'da yaşayan türlerin buzul buzullararası döngülere eşlik eden iklim değişikliklerine nasıl cevap verdiklerini (geçmişi) anlamak, hem Kuvaterner dinamiklerini/evrimsel tarihlerini, böylece Anadolu'nun biyocoğrafyasını/ biyolojik çeşitliliğini çözümlemek hem de yakın gelecekteki iklim değişikliğine nasıl cevap vereceklerini (geleceği) öngörmek, böylece koruma stratejilerini yönlendirmek açısından kritiktir. Aşağıda yukarıdaki içerik açısından

\section{Yeşil Ağaçkakan}

Yeşil ağaçkakan (Picus viridis), özellikle İberya ve İskandinavya hariç Avrupa kıtasının çok çeşitli yarı açık habitatlarında yaşayan diurnal (gündüzcül) bir kuş türüdür (Perktaş vd. 2011; BirdLife International 2016a).

Ekolojik niş modellemesi sonuçlarına göre, yeşil ağaçkakanın coğrafi dağılımı, Son Buzul Maksimum'dan günümüze genel olarak güney Avrupa'dan (İtalya, Balkanlar ve Anadolu) 
Avrupa'nın kuzeyine doğru genişlemiştir (Perktaş vd. 2015a; Perktaş 2017; Şekil 9). Bu genişleme örüntüsü, buzul sığınak tipinin ifade ettiği coğrafi dağılım değişiklikleri ile uyumludur. Ayrıca, yeşil ağaçkakan için Son Buzul Maksimum'da Fransa'da biyoiklimsel olarak uygun alanların olmas1, bu tür için bu bölgenin kriptik kuzey sığınak rolüne işaret eder (Şekil 9).

\section{Anadolu Yer Sincabı}

Anadolu yer sincabi (Spermophilus xanthoprymnus; Şekil 10), İç ve Doğu Anadolu, batı Ermenistan ve kuzeybatı İran'ın bozkır ve alpin çayırlarında yaşayan (toprak altında uyuyan ve kışı geçiren, toprak üstünde ise beslenen) diurnal ve hibernasyona (kış uykusuna) giren bir memeli türüdür. Neredeyse Anadolu'ya endemiktir (Kart Gür and Gür 2010). Yılın yaklaşık olarak yarısını veya daha uzun bir süreyi (Ağustos/Eylül ayından

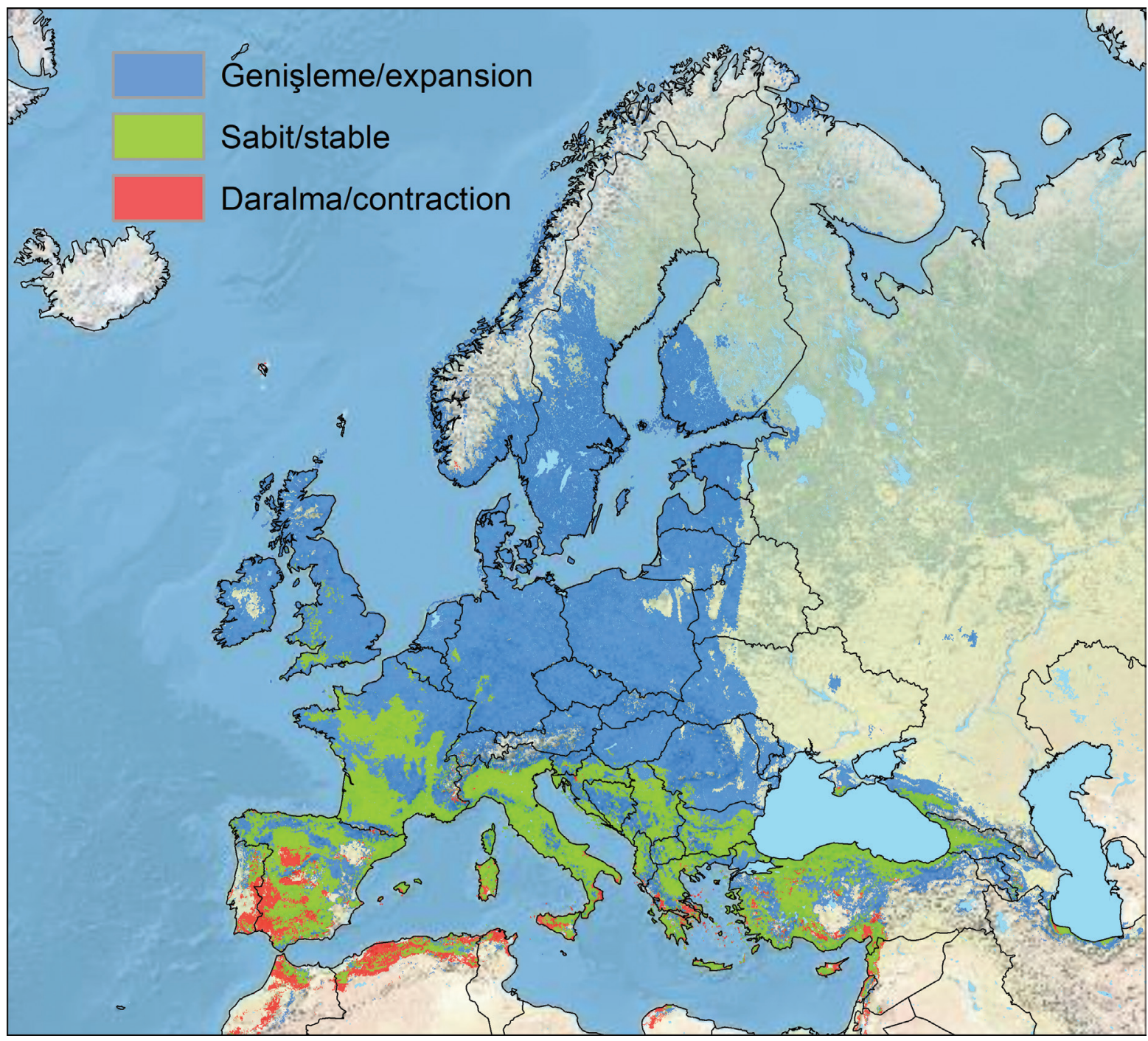

Şekil 9. Son Buzul Maksimum'dan günümüze Yeşil ağaçkakanın (Picus viridis) coğrafi dağılımındaki değişiklikler. Figure 9. Range shifts from the Last Glacial Maximum to the present in Green woodpecker (Picus viridis). 
Mart/Nisan ayına kadar) hibernasyonda geçirir (Gür and Kart Gür 2005; Kart Gür and Gür 2015, 2017).

Ekolojik niş modellemesi sonuçlarına göre, daha kurak ve mevsimsel iklime kitasal uyum sağlayan Anadolu yer sincabının coğrafi dağılımı, öngörüldüğü gibi, Son Buzul Maksimum'dan günümüze Anadolu'nun iç kesimlerine doğru daralmıştır (Şekil 11). Bu daralma örüntüsü, okyanusal-kıtasal gradiyentin kıtasal sığınaklar ayağı ile uyumludur (Gür 2013).

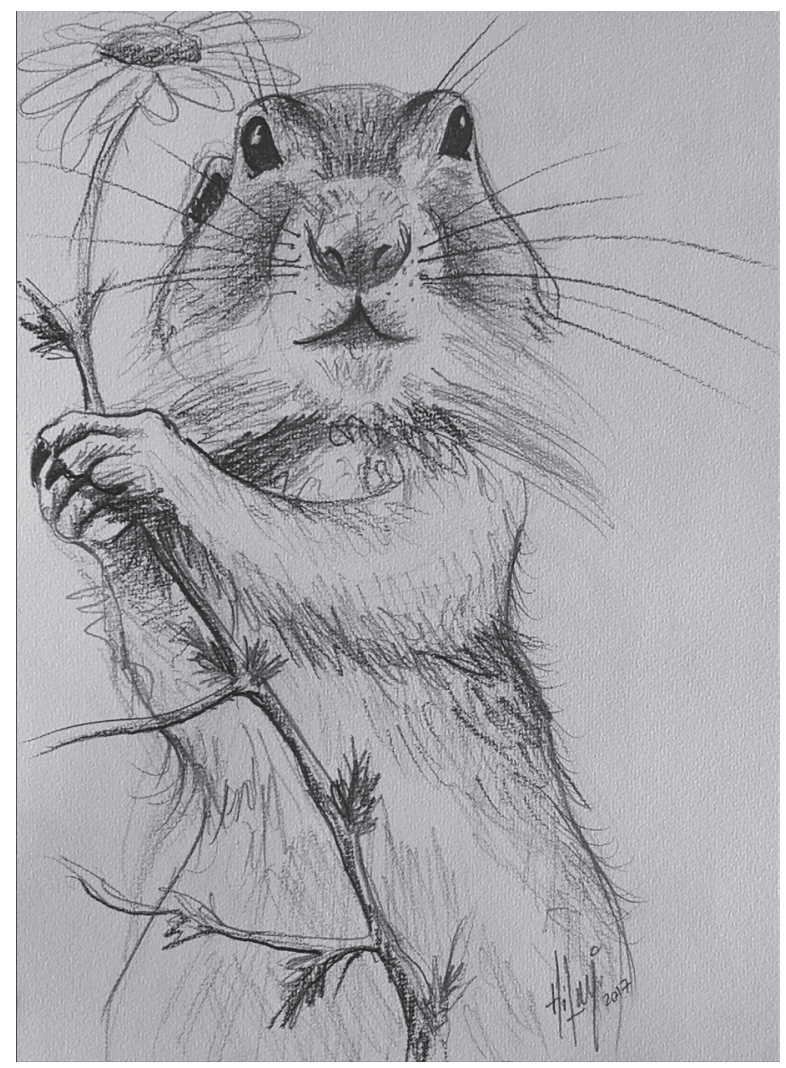

Şekil 10. Anadolu yer sincab1 (Spermophilus xanthoprymnus). Hilmi Şimşek (http://hilmisimsek. blogspot.com.tr/)

Figure 10. Anatolian ground squirrel (Spermophilus xanthoprymnus). Hilmi Şimşek (http://hilmisimsek. blogspot.com.tr/)

\section{Anadolu Sıvacı Kuşu}

Anadolu sıvacı kuşu (Sitta krueperi), Rusya'nın en güneyi, Gürcistan, Türkiye ve Midilli Adası'nın deniz seviyesinden 2,400 m'ye kadar yayılan 1lıman iğne yapraklı ormanlarında yaşayan diurnal bir kuş türüdür. Coğrafi dağılımı, büyük oranda Anadolu'nun kıyı kuşağından oluşur (Albayrak vd. 2012; Perktaş vd. 2015b; BirdLife International 2016b).

Ekolojik niş modellemesi sonuçlarına göre, Anadolu sıvacı kuşunun coğrafi dağılımı, Son Buzul Maksimum'dan günümüze genel olarak Anadolu'nun iç kesimlerine doğru genişlemiştir (Perktaş vd. 2015b; Perktaş 2017; Şekil 12). Bu genişleme örüntüsü, okyanusal-kıtasal gradiyentin okyanusal sığınaklar ayağı ile uyumludur ve Anadolu sıvacı kuşunun daha nemli ve daha az mevsimsel iklime uyum sağladığını ileri sürer.

\section{Toros Yer Sincabı}

Toros yer sincab1 (Spermophilus taurensis), Erenler Dağı ve Geyik Dağları'nın bozkır ve alpin çayırlarında yaşayan (toprak altında uyuyan ve kış1 geçiren, toprak üstünde ise beslenen) diurnal ve hibernasyona giren bir memeli türüdür. Batı Toros Dağları'na endemiktir. Anadolu yer sincabı ile karşılaştırıldığında, fizyolojisi, ekolojisi ve evrimi üzerine daha az bilgi mevcuttur (Gür vd. 2017).

Son Buzul Maksimum'da Akdeniz Bölgesi (Hughes and Woodward 2017) ve Anadolu'daki (Sarıkaya vd. 2011; Sarıkaya and Çiner 2015, 2017; Akçar vd. 2017) dağlarda olduğu gibi, Geyik Dağları'nda da buzullar gelişmiştir (Çiner vd. 2015). Geyik Dağları, Namaras Vadisi'ndeki dağ eteği buzullarının ilerlemesi ve gerilemesi, sirasiyla $>19.1 \pm 3.4$ ve $18.0 \pm 1.0$ bin $\mathrm{y} 1 \mathrm{l}$ öncesinde gerçekleşmiştir. Bu buzullar, yaklaşık 


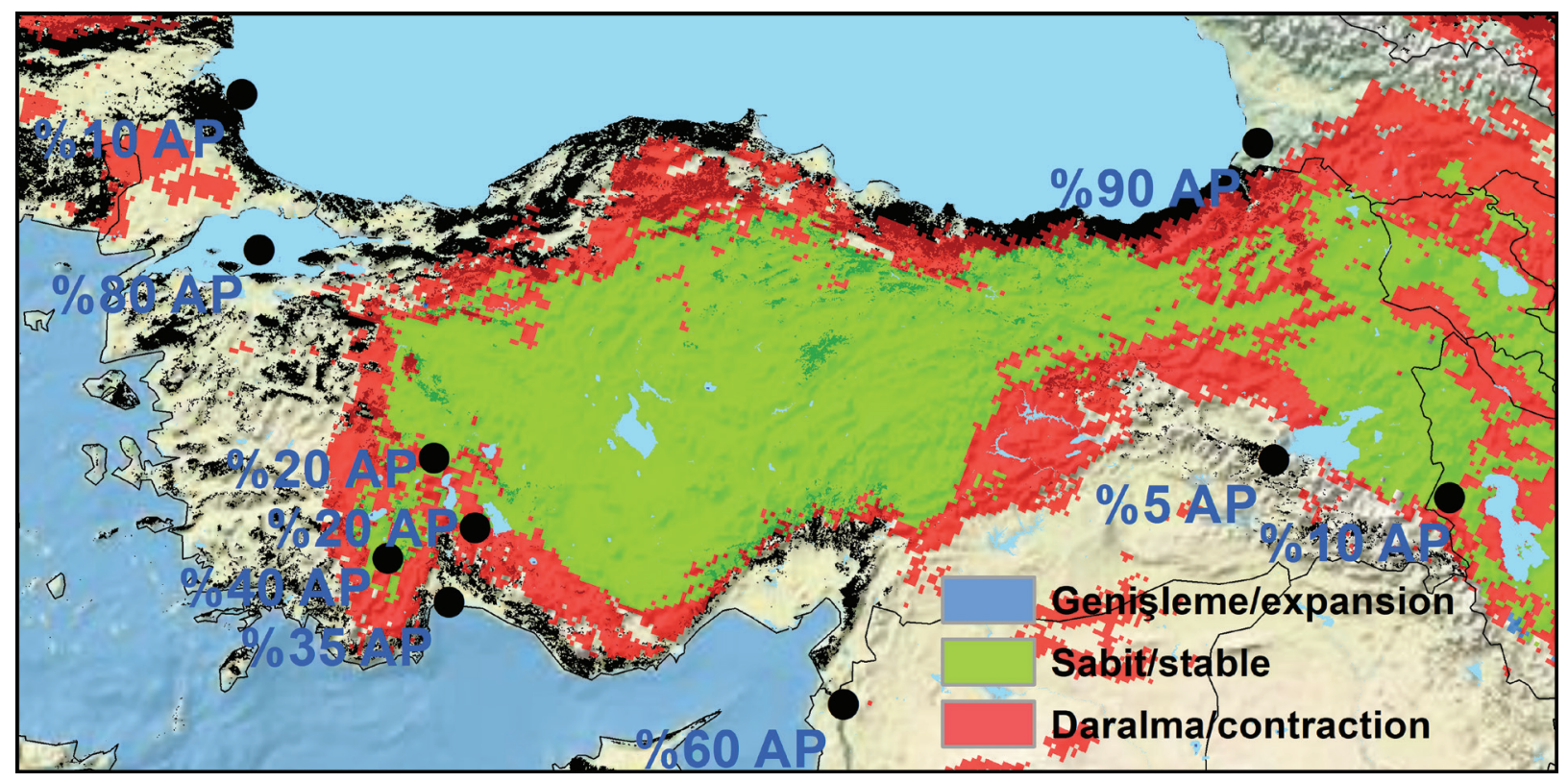

Şekil 11. Son Buzul Maksimum'dan günümüze Anadolu yer sincabının (Spermophilus xanthoprymnus) coğrafi dağılımındaki değişiklikler. Siyah noktalar Son Buzul Maksimum'daki ağaç poleni (AP) yüzdelerini (Şenkul and Doğan 2013'den), siyah alanlar ise günümüzde orman örtüsünün \%50'nin üzerinde olduğu yerleri gösterir (Forest Europe 2011'e dayanarak çizilmiştir).

Figure 11. Range shifts from the Last Glacial Maximum to the present in Anatolian ground squirrel (Spermophilus xanthoprymnus). Black points show arboreal pollen (AP) percentages in the Last Glacial Maximum (from Şenkul and Doğan 2013) and black areas the areas where forest cover is $\geq 50 \%$ in the present (drawn based on Forest Europe 2011).

2000 m'ye kadar inmiş ve yaklaşık 4 km uzunluğa ulaşmıştır (Çiner vd. 2015). Böylece, ekolojik niş modellemesi sonuçlarına göre, Toros yer sincabının coğrafi dağılımı, öngörüldüğü gibi, Son Buzul Maksimum'dan günümüze genel olarak düşük rakımlardan yüksek rakımlara doğru değişmiştir. Yani, düşük rakımlar terk edilirken, yüksek rakımlar kolonize edilmiştir (Gür vd.2017). Özellikle Geyik Dağları'nın denize bakan yamaçlarını Toros yer sincabı terk ederken, ormanlar kolonize etmiştir (Şekil 13).

Son Buzul Maksimum'da Anadolu'da buzul gelişimi için iklimsel olarak uygun alanlar (bkz. Şekil 6), aynı zamanda rakımsal hareketleri çalışmak açısından da en uygun alanlar olarak değerlendirilebilir. Toros yer sincabının Geyik Dağları'nın buzul tarihi ile ilişkili rakımsal hareketleri, bunu doğrular niteliktedir.

$\mathrm{Bu}$ yazıda, sadece buzullararası sığınaklar açısından bir örnek verilememiştir. Ancak Anadolu'dan verilebilecek örnek, soğuğa uyum sağlayan türler ve (bu sığınakların genel olarak kuzey Avrasya'da konumlandığı düşünüldüğünde) kriptik güney sı̆̆ınaklar ile ilgili olabilir. Yani, Anadolu, SonBuzulMaksimum' da coğrafi dağılımı daha geniş, günümüzde (içinde bulunduğumuz buzullararası dönemde) ise ana dağılımı kuzey Avrupa' da olan, ancak Anadolu'nun dağlarında da yaşayan soğuğa uyum sağlayan türler için kriptik güney sığınak olarak düşünülebilir. 


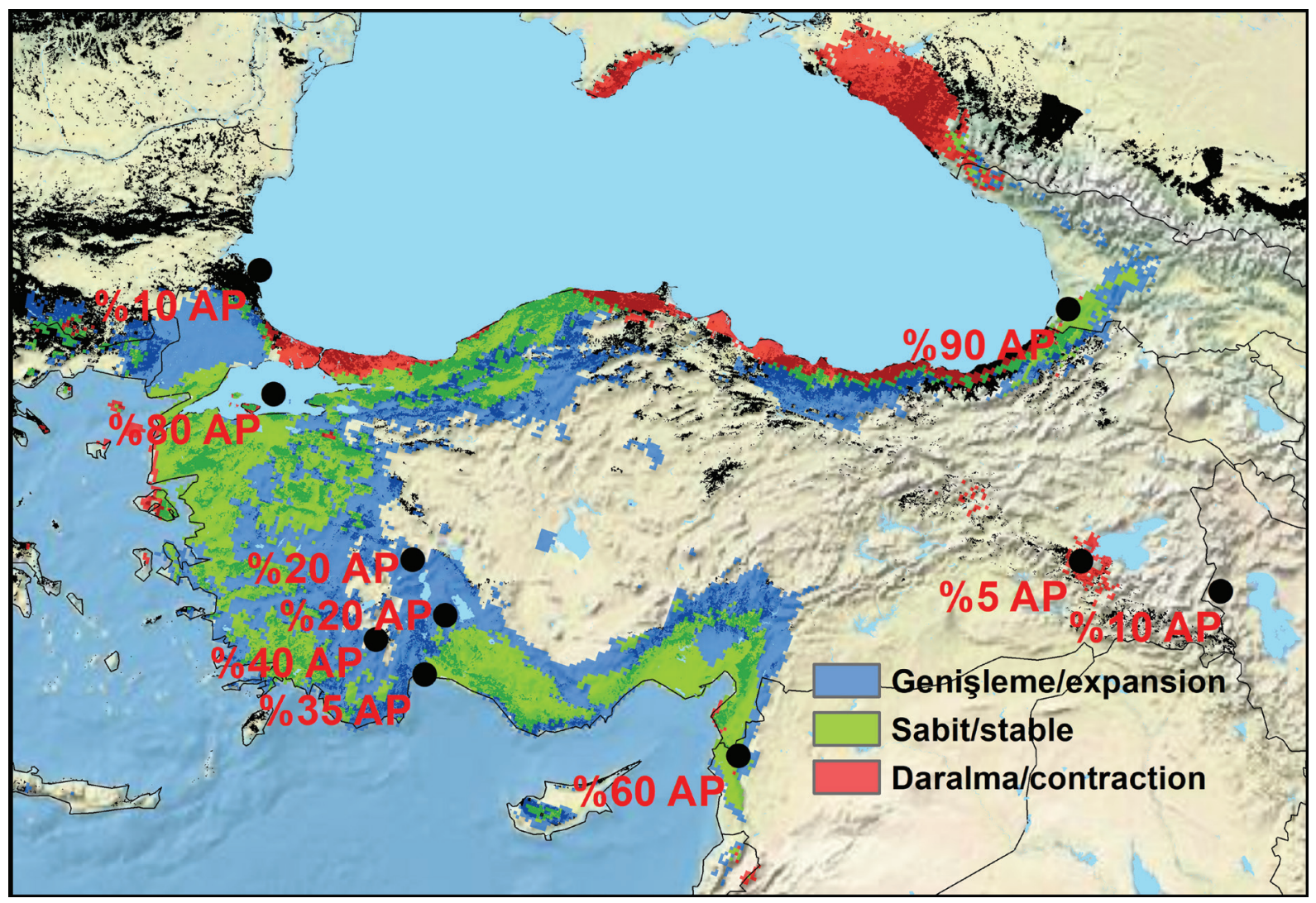

Şekil 12. Son Buzul Maksimum'dan günümüze Anadolu sıvacı kuşunun (Sitta krueperi) coğrafi dağılımındaki değişiklikler. Siyah noktalar Son Buzul Maksimum'daki ağaç poleni (AP) yüzdelerini (Şenkul and Doğan 2013'den), siyah alanlar ise günümüzde orman örtüsünün \%50'nin üzerinde olduğu yerleri gösterir (Forest Europe 2011'e dayanarak çizilmiştir).

Figure 12. Range shifts from the Last Glacial Maximum to the present in Krüper's nuthatch (Sitta krueperi). Black points show arboreal pollen (AP) percentages in the Last Glacial Maximum (from Şenkul and Doğan 2013) and black areas the areas where forest cover is $\geq 50 \%$ in the present (drawn based on Forest Europe 2011).

Peki, tüm bu örnekler, Son Buzul Maksimum'dan günümüze Anadolu'nun bitki örtüsündeki değişiklikler açısından nasıl yorumlanabilir? 23-19 bin yıl önceleri (Son Buzul Maksimum'da) Anadolu'nun kuzeyinde, özellikle de kıyı kuşağında soğuk veya serin ve nemli iklim koşulları altında yoğun bir orman örtüsü (ağaç poleni oranı \% 90) vardı. Benzer şekilde, Anadolu'nun Akdeniz kıyı kuşağında soğuk ve nemli iklim koşulları altında bütün vejetasyonun \%50-60'1n1 orman oluşturuyordu (Şenkul and Doğan 2013; bkz. Şekil 11 ve 12). Yani, Son Buzul Maksimum'da Anadolu'nun kıyı kuşağı orman örtüsüne sahipti (bkz. ayrıca
Tarkhnishvili vd. 2012). Anadolu'nun özellikle iç kesimlerini içerecek şekilde Yakın Doğu'da ise soğuk ve kurak iklim koşulları altında bozkır örtüsü yaygındı (Atalay 1998). Genel olarak, Son Buzul Maksimum'dan günümüze Anadolu'nun iç kesimlerine doğru bozkırlar daralmış, ormanlar ise genişlemiş olmalıdır. Tüm bu örnekler, Son Buzul Maksimum'dan günümüze Anadolu'nun bitki örtüsündeki değişiklikler ile uyumludur. Örneğin, Son Buzul Maksimum'dan günümüze ormanların genişlemesine paralel olarak Anadolu sıvacı kuşu coğrafi dağılımını genişletmiş, bozkırların daralmasına paralel olarak Anadolu yer sincabı ise coğrafi dağılımını daraltııştır. 


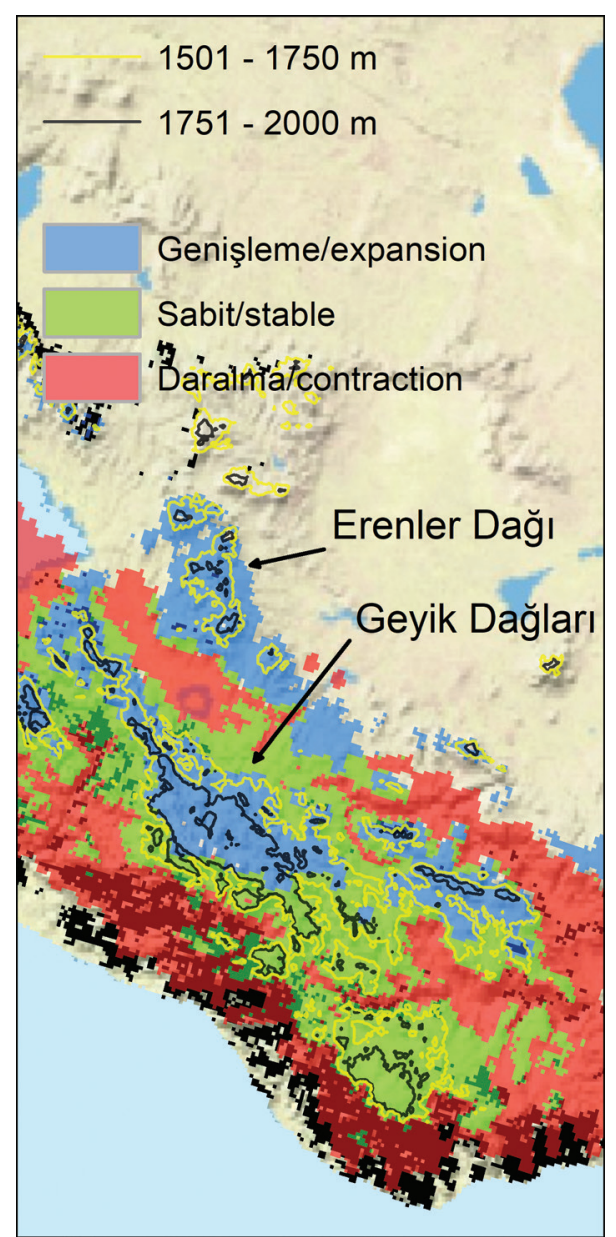

Şekil 13. Son Buzul Maksimum'dan günümüze Toros yer sincabının (Spermophilus taurensis) coğrafi dağılımındaki değişiklikler. Siyah alanlar, günümüzde orman örtüsünün \%50'nin üzerinde olduğu yerleri gösterir (Forest Europe 2011'e dayanarak çizilmiştir).

Figure 13. Range shifts from the Last Glacial Maximum to the present in Taurus ground squirrel (Spermophilus taurensis). Black areas show the areas where forest cover is $\geq 50 \%$ in the present (drawn based on Forest Europe 2011).

Anadolu'da yaşayan türlerin buzul buzullararası döngülere eşlik eden iklim değişikliklerine nasıl cevap verdiklerini (geçmişi) anlamanın yakın gelecekteki iklim değişikliğine nasıl cevap vereceklerini (geleceği) öngörmek açısından önemli olduğunu vurgulamıştık. Bunu, yukarıdaki örneklerden biri açısından detaylandıralım. Özellikle günümüz gibi buzullararası dönemlerde coğrafi dağılımlarını daraltan türlerin 21. yüzyılda gerçekleşecek iklim değişikliğinin etkilerine daha açık olmaları beklenir (Ashcroft 2010); diğer bir deyişle, 21. yüzyılda küresel sıcaklığın daha da artması, zaten günümüzde (diğer buzullararası dönemlerde olduğu gibi) coğrafi dağılımlarını daraltmış olan türleri daha fazla tehdit edecektir. Anadolu yer sincabının coğrafi dağılımının buzullararası dönemlerde genel olarak Anadolu'nun iç ve/ veya doğu kesimlerine (kıtasal sığınaklara) doğru daralması, daha kurak ve mevsimsel iklime kitasal uyum sağladiğı düşünüldüğ̈ünde ve okyanusalkıtasal gradiyente dayanarak, tam da öngörüldüğü gibidir. Bu, Anadolu yer sincabının coğrafi dağılımının 21. yüzyılda küresel sicaklığın daha da artması ile birlikte daralmaya devam edeceğini ileri sürer (bkz. önsel sonuçlar için, Gür 2016c,d).

Anadolu'da hem geçmişi anlamak hem de geleceği öngörmek açısından bu tür çalışmalar, özellikle biyolojik çeşitlilik ile ilgili ulusal veri tabanlarına ve alansal ve zamansal olarak çeşitlendirilmiş iklim modellerine gereken önem verilerek, yüksek takson (örneğin, tüm kuşları, memelileri vb. içerecek şekilde) düzeyinde gerçekleştirilmelidir!

\section{SONSÖZ}

Tüm bu örnekler, Anadolu'nun buzul buzullararası döngülerden daha az etkilendiğini ve buna rağmen, 'sığınaklar içinde sığınaklar' modeli ile uyumlu olarak, yine de coğrafi dağılımların döngüsel bir şekilde daralması ve genişlemesine sahne olduğunu doğrular. Sonuç olarak, (1) buzul buzullararası döngülerden daha az etkilenmesi, böylece türlere/popülasyonlara daha uzun dönemli ev sahipliği yapması (ki bu, genetik çeşitliliğin birikmesi için daha uzun bir zaman anlamına gelir); (2) bu döngülerden daha az etkilenmesine rağmen, yine de coğrafi dağılımların döngüsel bir şekilde daralması ve genişlemesine sahne 
olması, böylece genetik çeşitlilik birikirken, aynı zamanda türlerin/popülasyonların farklılaşmasına izin vermesi ve (3) sığınak rolünün karmaşık doğası (örneğin, hem buzul hem de kıtasal sığınak olmasi; ki bu, hem konumu hem de jeolojik ve iklimsel dinamikleri ile ilişkilidir), Anadolu'nun biyolojik çeşitliliğini şekillendiren önemli etkenler arasındadır.

\section{KATKI BELIRTME}

Türkiye Jeoloji Bülteni'nin bu özel sayısına katkı sunmak için beni davet eden misafir editör $M$. Korhan Erturaç'a ve önerileri için hakemlere ve Çağatay Tavşanoğlu'na teşekkür ederim. Ayrıca, akademik yaşamımda birçok çalışmayı birlikte gerçekleştirdiğimiz meslektaşlarım Ahi Evran Üniversitesi'nden Mutlu Kart Gür'e ve Hacettepe Üniversitesi'nden Utku Perktaş'a en içten teşekkürlerimi sunarım.

\section{EXTENDEND SUMMARY}

Large continental ice-sheets in the Northern Hemisphere have grown and retreated many times throughout the Quaternary. Times with and without large continental ice-sheets are known as glacial and interglacial periods, respectively (Past Interglacials Working Group of PAGES 2016). The last $430 \mathrm{kyr}$ have been dominated by 100-kyr glacial-interglacial cycles, a minor proportion (on average $20 \%$ or 10 to $30 \mathrm{kyr}$ ) of which was spent in interglacial periods (Jansen et al. 2007). Strong climatic fluctuations accompanying these glacialinterglacial cycles forced species to either move to locations that remain suitable, adapt to changing environmental conditions, or go extinct (Jansson and Dynesius 2002). Latitudinal and altitudinal range shifts are the most conspicuous and best documented responses of warm-adapted temperate and cold-adapted montane species to these climatic fluctuations, respectively. As warming has occurred since the Last Glacial Maximum, temperate and montane species shifted their range towards higher (northern) latitudes and altitudes, respectively (Bennett and Provan 2008; Stewart et al. 2010). These range shifts have left signals of high genetic diversity in refugia and low genetic diversity in regions recently colonized from refugia (Hewitt 2000, 2004a,b). Understanding how species have responded to strong climatic fluctuations accompanying glacial-interglacial cycles is critical to predicting their likely responses to future global climate changes, and therefore can help guide conservation strategies.

To understand how species have responded to global climate changes through the Late Quaternary glacial-interglacial cycles, ecological niche modelling, together with molecular phylogeography, has been widely used in recent biogeographic studies (Perktaş and Gür 2015). Molecular phylogeography uses DNA sequences from throughout the geographic distribution of species to understand the spatial arrangements of genetic diversity in the past and in the present (Avise et al. 1987; Avise 2000). Ecological niche modelling relates georeferenced species occurrence data to environmental data, and can be used to get insights into possible climate-driven range shifts in the past (e.g. the Last Glacial Maximum) and in the future (Peterson et al. 2011).

Anatolia is geologically located in the AlpineHimalayan orogenic belt (Şengör and Yllmaz 1981), and a biogeographically interesting, but under-explored region where three of the world's 36 biodiversity hotspots meet, and interact, with high levels of species diversity and endemism (Conservation International 2017). Ecological niche modelling, together with molecular phylogeography, will extend the Quaternary dynamics and evolutionary history of species living in Anatolia and therefore the understanding of the biogeography of Anatolia. In this article, a few examples regarding bird and mammal species (Gür 2013; Perktaş et al. 2015a,b; Gür et al. 2017) were given to illustrate the above- 
mentioned contents, and the future perspectives were discussed.

\section{ORCID}

Hakan Gür (D) https://orcid.org/0000-0003-4554-4370

\section{DEĞINILEN BELGELER}

Akçar, N., Yavuz, V., Yeşilyurt, S., Ivy-Ochs, S., Reber, R., vd., 2015. A synchronous Last Glacial Maximum across the Anatolian peninsula. In: Quaternary Glaciation in the Mediterranean Region. Hughes, P.D. and Woodward, J.C. (eds.) Geological Society, London, Special Publications, 433, pp. 251-269.

Albayrak, T., Gonzalez, J., Drovetski, S.V. and Wink, M., 2012. Phylogeography and population structure of Krüper's Nuthatch Sitta krueperi from Turkey based on microsatellites and mitochondrial DNA. Journal of Ornithology, 153 (2) 405-411.

Ansell, S.W., Stenøien, H.K., Grundmann, M., Russell, S.J., Koch, M.A., vd., 2011. The importance of Anatolian mountains as the cradle of global diversity in Arabis alpina, a key arctic-alpine species. Annals of Botany, 108 (2) 241-252.

Ashcroft, M.B., 2010. Identifying refugia from climate change. Journal of Biogeography, 37 (8) 14071413.

Atalay, İ., 1998. Paleoenvironmental conditions of the Late Pleistocene and Early Holocene in Anatolia, Turkey. In: Quaternary Deserts and Climatic Change. Alsharhan, A.S., Glennie, K.W., Whittle, G.L. and Kendall, C.G.St.C. (eds.) A.A. Balkema, Rotterdam, pp. 227-237.

Avise, J.C., 2000. Phylogeography: the History and Formation of Species. Harvard University Press, Cambridge.

Avise, J.C., Arnold, J., Ball, R.M., Bermingham, E., Lamb, T., vd., 1987. Intraspecific phylogeography: the mitochondrial DNA bridge between population genetics and systematics. Annual Review of Ecology and Systematics, 18 (1) 489-522.

Bennett, K.D. and Provan, J., 2008. What do we mean by 'refugia'? Quaternary Science Reviews, 27 (27-28) 2449-2455.

Bilgin, R., Gürün, K., Rebelo, H., Puechmaille, S.J., Marac1, Ö., vd., 2016. Circum-Mediterranean phylogeography of a bat coupled with past environmental niche modeling: a new paradigm for the recolonization of Europe? Molecular Phylogenetics and Evolution, 99 323-336.

BirdLife International. 2016a. Picus viridis. The IUCN Red List of Threatened Species 2016: e.T22725022A87292744.

BirdLife International. 2016b. Sitta krueperi. The IUCN Red List of Threatened Species 2016: e.T22711184A94282660.

Cohen, K.M., Finney, S.C., Gibbard, P.L. and Fan, J-X., 2013. The ICS international chronostratigraphic chart. Episodes, 36 (3) 199-204.

Conservation International, 2017. Conservation International: Hotspots. http://www.conservation. org/how/pages/hotspots.aspx Erişim tarihi 10 Ekim 2017.

Cowie, J., 2007. Climate Change: Biological and Human Aspects. Cambridge University Press, Cambridge.

Çiner, A., Sarıkaya, M.A. and Yıldırım, C., 2015. Late Pleistocene piedmont glaciations in the Eastern Mediterranean; insights from cosmogenic $36 \mathrm{Cl}$ dating of hummocky moraines in southern Turkey. Quaternary Science Reviews, 116 44-56.

Darwin, C., 1859. On the Origin of Species by Means of Natural Selection, or the Preservation of Favoured Races in the Struggle for Life. John Murray, London. Çeviri: Kılıç, B., 2017. Türlerin Kökeni. Alfa Yayıncilık, İstanbul.

Ehlers, J., Gibbard, P.L. and Hughes, P.D., (eds.) 2011. Quaternary Glaciations - Extent and Chronology, A Closer Look. Elsevier, Amsterdam.

Elith, J., Kearney, M. and Phillips, S., 2010. The art of modelling range-shifting species. Methods in Ecology and Evolution, 1 (4) 330-342.

Elith, J., Graham, C.H., Anderson, R.P., Dudík, M., Ferrier, S., vd., 2006. Novel methods improve prediction of species' distributions from occurrence data. Ecography, 29 (2) 129-151.

Elith, J., Phillips, S.J., Hastie, T., Dudík, M., Chee, Y.E., vd., 2011. A statistical explanation of MaxEnt for ecologists. Diversity and Distributions, 17 (1) 4357.

Forest Europe, 2011. State of Europe's Forests 2011 - Status and Trends in Sustainable Forest Management in Europe, jointly prepared by Forest Europe Liaison Unit Oslo, the United Nations Economic Commission for Europe (UNECE) and 
the Food and Agricultural Organization of the United Nations (FAO).

Gómez, A. and Lunt, D.H., 2007. Refugia within refugia: patterns of phylogeographic concordance in the Iberian Peninsula. In: Phylogeography of Southern European Refugia. Weiss, S. and Ferrand, N. (eds.) Springer, Netherlands, pp. 155188.

Gribbin, J., 2002. Science: A History 1543-2001. Allen Lane. Çeviri: Gönülşen, B., 2014. Bilim Tarihi. Alfa Yayınc1lık, İstanbul.

Gribbin, J. and Gribbin, M., 2002. Ice Age: How a Change of Climate Made Us Human. Penguin Books Ltd, London.

Gür, H., 2013. The effects of the late Quaternary glacialinterglacial cycles on Anatolian ground squirrels: range expansion during the glacial periods? Biological Journal of the Linnean Society, 109 (1) 19-32.

Gür, H., 2016a. Doğal seçilim yoluyla evrim, güncel bir örnek: alacabaykuş. Evrimin Işığında. Akış, I. ve Altınışık, N.E. (Editörler) Yazılama Yayınevi, İstanbul, s. 197-206.

Gür, H., 2016b. The Anatolian diagonal revisited: testing the ecological basis of a biogeographic boundary. Zoology in the Middle East, 62 (3) 189199.

Gür, H., 2016c. İklim değişikliği ve bir step hayvanı olan Anadolu yer sincabı - 1: İklim değişikliği nedir, biyolojik sistemleri nasıl etkiler? Bilim ve Gelecek, 143 78-83.

Gür, H., 2016d. İklim değişikliği ve bir step hayvanı olan Anadolu yer sincabı - 2: İklim değişikliği Anadolu yer sincabını nasıl etkiliyor? Bilim ve Gelecek, 144 76-81.

Gür, H., 2017. Anadolu diyagonali: bir biyocoğrafi sınırın anatomisi. Kebikeç, İnsan Bilimleri İçin Kaynak Araştırmaları Dergisi, 43 177-187.

Gür, H. and Kart Gür, M., 2005. Annual cycle of activity, reproduction, and body mass of Anatolian ground squirrels (Spermophilus xanthoprymnus) in Turkey. Journal of Mammalogy, 86 (1) 7-14.
Gür, H., Perktaş, U. and Kart Gür, M., unpublished. Do climate-driven altitudinal range shifts explain the intraspecific diversification of a narrow ranging montane mammal, Taurus ground squirrels?

Hamann, A., Roberts, D., Barber, Q., Carroll, C. and Nielsen, S., 2015. Velocity of climate change algorithms for guiding conservation and management. Global Change Biology, 21 (2) 997 1004 .

Hewitt, G., 2000. The genetic legacy of the Quaternary ice ages. Nature, 405 (6789) 907-913.

Hewitt, G.M., 2004a. Genetic consequences of climatic oscillations in the Quaternary. Philosophical Transactions of the Royal Society of London B: Biological Sciences, 359 (1442) 183-195.

Hewitt, G.M., 2004b. The structure of biodiversity - insights from molecular phylogeography. Frontiers in Zoology, 1 (1) 4.

Hughes, P.D. and Woodward, J.C., 2017. Quaternary glaciation in the Mediterranean mountains: a new synthesis. In: Quaternary Glaciation in the Mediterranean Region. Hughes, P.D. and Woodward, J.C. (eds.) Geological Society, London, Special Publications, 433, pp. 1-23.

Hutchinson, G.E., 1957. Concluding remarks. Cold Spring Harbor Symposia on Quantitative Biology, 22 415-427.

Jansen, E., Overpeck, J., Briffa, K.R., Duplessy, J.-C., Joos, F., vd., 2007. Palaeoclimate. In: Climate Change 2007: The Physical Science Basis. Contribution of Working Group I to the Fourth Assessment Report of the Intergovernmental Panel on Climate Change. Solomon, S., Qin, D., Manning, M., Chen, Z., Marquis, M., vd. (eds.) Cambridge University Press, Cambridge, UK, and New York, pp. 433-497.

Jansson, R. and Dynesius, M., 2002. The fate of clades in a world of recurrent climatic change: Milankovitch oscillations and evolution. Annual Review of Ecology and Systematics, 33 741-777.

Kart Gür, M. and Gür, H., 2010. Spermophilus xanthoprymnus. Mammalian Species, 42 (1) 183194.

Kart Gür, M. and Gür, H., 2015. Age and sex differences in hibernation patterns in free-living Anatolian ground squirrels. Mammalian Biology, 80 (4) 265272. 
Kart Gür, M. and Gür, H., 2017. Küçük bir memeli türünün ekofizyolojisi ve evrimsel coğrafyasi: Anadolu yer sincabı. Kebikeç, İnsan Bilimleri İçin Kaynak Araştırmaları Dergisi, 43 189-198.

Koch, M.A., Kiefer, C., Ehrich, D., Vogel, J., Brochmann, C., vd., 2006. Three times out of Asia Minor: the phylogeography of Arabis alpina L.(Brassicaceae). Molecular Ecology, 15 (3) 825839.

Korkmaz, E.M., Lunt, D.H., Çıplak, B., Değerli, N. and Başıüyük, H.H., 2014. The contribution of Anatolia to European phylogeography: the centre of origin of the meadow grasshopper, Chorthippus parallelus. Journal of Biogeography, 41 (9) 17931805.

Past Interglacials Working Group of PAGES, 2016. Interglacials of the last 800,000 years. Reviews of Geophysics, 54 162-219.

Perktaş, U., 2017. Filocoğrafya: coğrafi varyasyon örüntüleriyle geçmişe bakmak. Kebikeç, İnsan Bilimleri İçin Kaynak Araştırmaları Dergisi, 43 143-156.

Perktaş, U. and Gür, H., 2015. Guest editors' introduction to the special issue: integrating phylogeography and ecological niche modelling. Folia Zoologica, 64 (3) 185-186.

Perktaş, U., Barrowclough, G.F. and Groth, J.G., 2011. Phylogeography and species limits in the green woodpecker complex (Aves: Picidae): multiple Pleistocene refugia and range expansion across Europe and the Near East. Biological Journal of the Linnean Society, 104 (3) 710-723.

Perktaş, U., Gür, H. and Ada, E., 2015a. Historical demography of the Eurasian green woodpecker: integrating phylogeography and ecological niche modelling to test glacial refugia hypothesis. Folia Zoologica, 64 (3) 284-295.

Perktaş, U., Gür, H., Sağlam, İ.K. and Quintero, E., 2015b. Climate-driven range shifts and demographic events over the history of Kruper's Nuthatch Sitta krueperi. Bird Study, 62 (1) 14-28.

Peterson, A.T., Soberón, J., Pearson, R.G., Anderson, R.P., Martinez-Meyer, E., vd., 2011. Ecological Niches and Geographical Distributions. Princeton University Press, Princeton, New Jersey.

Phillips, S.J., Anderson, R.P. and Schapire, R.E., 2006. Maximum entropy modeling of species geographic distributions. Ecological Modelling, 190 (3) 231-259.
Richards, C.L., Carstens, B.C. and Lacey Knowles, L., 2007. Distribution modelling and statistical phylogeography: an integrative framework for generating and testing alternative biogeographical hypotheses. Journal of Biogeography, 34 (11) 1833-1845.

Rokas, A., Atkinson, R.J., Webster, L., Csóka, G. and Stone, G.N., 2003. Out of Anatolia: longitudinal gradients in genetic diversity support an eastern origin for a circum Mediterranean oak gallwasp Andricus quercustozae. Molecular Ecology, 12 (8) 2153-2174.

Sandel, B., Arge, L., Dalsgaard, B., Davies, R.G., Gaston, K.J., vd., 2011. The influence of late quaternary climate-change velocity on species endemism. Science, 334 (6056) 660-664.

Sarıkaya, M.A. and Çiner, A., 2015. Late Pleistocene glaciations and paleoclimate of Turkey. Bulletin of the Mineral Research and Exploration, 151 107-127.

Sarıkaya, M.A. and Çiner, A., 2017. Late Quaternary glaciations in the eastern Mediterranean. In: Quaternary Glaciation in the Mediterranean Region. Hughes, P.D. and Woodward, J.C. (eds.) Geological Society, London, Special Publications, 433, pp. 289-305.

Sarkaya, M.A., Çiner, A. and Zreda, M., 2011. Quaternary glaciations of Turkey. In: Quaternary Glaciations - Extent and Chronology, A Closer Look. Ehlers, J., Gibbard, P.L. and Hughes, P.D. (eds.) Elsevier, Amsterdam, pp. 393-403.

Stewart, J.R., Lister, A.M., Barnes, I. and Dalén, L., 2010. Refugia revisited: individualistic responses of species in space and time. Proceedings of the Royal Society B: Biological Sciences, 277 (1682) 661-671.

Şekercioğlu, Ç.H., Anderson, S., Akçay, E., Bilgin, R., Can, Ö.E., vd., 2011. Turkey's globally important biodiversity in crisis. Biological Conservation, 144 (12) 2752-2769.

Şengör, A.M.C. and Yılmaz, Y., 1981. Tethyan evolution of Turkey - a plate tectonic approach. Tectonophysics, 75 (3-4) 181-241.

Şenkul, Ç. and Doğan, U., 2013. Vegetation and climate of Anatolia and adjacent regions during the Last Glacial period. Quaternary international, 302 110122. 
Tarkhnishvili, D., Gavashelishvili, A. and Mumladze, L., 2012. Palaeoclimatic models help to understand current distribution of Caucasian forest species. Biological Journal of the Linnean Society, 105 (1) 231-248.
Tavşanoğlu, Ç., 2016. Anadolu'nun yüksek biyoçeşitliliği: evrim bunun neresinde? Akış, I. ve Altınışık, N.E. (Editörler) Yazılama Yayınevi, İstanbul, s. 207-225. 